\title{
LITHOSTRATIGRAPHY OF ZECHSTEIN EVAPORITES OF THE CENTRAL AND NORTH-WESTERN PARTS OF THE MOGILNO SALT DIAPIR, BASED ON BOREHOLES Z-9 AND Z-17
}

\author{
Litostratygrafia ewaporatów cechsztyńskich \\ w centralnej i pólnocno-zachodniej części wysadu solnego Mogilno, \\ na podstawie danych $\mathrm{z}$ otworów Z-9 i Z-17
}

\author{
Jacek WACHOWIAK ${ }^{1}$, Maciej PAWLIKOWSKI ${ }^{1} \&$ Pawel WILKOSZ $^{2}$ \\ ${ }^{1}$ AGH Akademia Górniczo-Hutnicza, Wydział Geologii, Geofizyki i Ochrony Środowiska, \\ Katedra Mineralogii, Petrografii i Geochemii; al. A. Mickiewicza 30, 30-059 Kraków; \\ e-mail:mpawlik@agh.edu.pl,psgs@agh.edu.pl \\ ${ }^{2}$ Investgas SA; al. Jana Pawła II 70, 00-175 Warszawa; \\ e-mail: pawel.wilkosz@investgas.pl
}

\begin{abstract}
This paper presents the results of comprehensive mineralogical and petrographic studies conducted on evaporite rocks of the Zechstein (Upper Permian) period, extracted from boreholes drilled in the Mogilno diapir. Based on the research results, the occurrence of rock salts, potash-magnesium salts (kieseritic sylvinites), clayey salts, zubers, and anhydrites was identified. Those formations were assigned to cyclothems PZ-3 and PZ-2. No presence of evaporites belonging to cyclothems PZ-1 and PZ-4 were discovered. The recognized rocks were mainly composed of halite, sylvine, kieserite and anhydrite. Smaller quantities of polyhalite, kainite, carbonates and clayey minerals were also found. A number of accessory minerals were identified, with their salt rock contents from several to about several tens of ppm
\end{abstract}

Key words: Upper Permian in Poland, Zechstein evaporites, Zechstein lithostratigraphy, rock salt, potash-magnesium salts, salt minerals, Mogilno Salt Diapir

Treść: W artykule przedstawiono wyniki kompleksowych badań mineralogiczno-petrograficznych, przeprowadzonych na skałach ewaporatowych wieku cechsztyńskiego (górny perm) napotkanych w badawczych otworach wiertniczych w wysadzie solnym Mogilno. Na podstawie otrzymanych wyników stwierdzono w badanych otworach sole kamienne, sole potasowo-magnezowe (sylwinity kizerytowe), sole ilaste, zubry i anhydrytowce. Powyższe utwory przydzielono do cyklotemów PZ-3 i PZ-2. Nie stwierdzono obecności ewaporatów cyklotemów PZ-1 i PZ-4. Rozpoznane skały zbudowane są głównie z halitu, sylwinu, kizerytu, anhydrytu. W mniejszych ilościach występują polihalit, kainit, węglany i minerały ilaste. Zidentyfikowano wiele minerałów akcesorycznych, których zawartość w skałach solnych jest rzędu ppm.

Słowa kluczowe: górny perm, ewaporaty cechsztyńskie, litostratygrafia cechsztynu, sól kamienna, sole potasowo-magnezowe, minerały solne, wysad solny Mogilno 


\section{INTRODUCTION}

The Mogilno salt diapir is one of the salt deposits situated on the Polish Lowlands that are industrially exploited. In respect of mining operations, the diapir has been divided into two parts: south-eastern called Mogilno, where salt is extracted by solution mining by the IKS Solino SA, and the north-western one called Mogilno II, where solution mining is conducted by Investgas SA to develop underground natural-gas storage caverns for KPMG Mogilno. Mining of salt diapirs, especially for the construction and safe operation of underground fuel storage facilities, required a detailed recognition of internal diapir structures. Owing to the solution mining process, the boreholes and cores with rock samples remain the only available objects of research. The development of a deposit structure model, based on limited materials, required a comprehensive application of the most recent geological research methods. One of the study elements is the mineralogical and petrographic analysis and interpretation of the extracted rocks. In 2011, acting to the order of Investgas SA, comprehensive mineralogical and petrographic studies of evaporite rocks, originating from boreholes Z-9 and Z-17, were conducted at AGH University of Science and Technology in Kraków (Wachowiak \& Pawlikowski 2011a, b) Their purpose was to determine petrographic parameters of the studied boreholes, with specification of a detailed mineral composition and determination of the age structure (or stratigraphic identification) of the recognized rocks, together with depth intervals, proper in petrographic terms, for the placement of storage caverns. In this paper, we present the lithostratigraphic results of the studies. The mineral test results will be the object of a separate publication.

\section{GEOLOGICAL SETTING}

Salt domes are one of the most characteristic structural elements for the Zechstein deposits in the Polish Basin (Fig. 1). The axial zone of the basin has the NW-SE orientation and is called the Mid-Polish Trough (MPT). The basin belonged to the system of epicontinental depositional basins of Western and Central Europe, and it constituted the axial part of the Danish-Polish Basin (Dadlez 1997, Krzywiec 2006).

Several tens of salt structures have been recognized in the Polish Basin (Garlicki \& Szybist 1986, Dadlez 1997, Dadlez \& Marek 1998). They are of various sizes and represent a wide range of the cyclothems of Mesozoic cover rocks pierced by salt (Fig. 1). Ten salt diapirs cut the upper denudational structural surface of the Mesozoic deposits and penetrate the cover of the Kenozoic rocks. The Mogilno salt dome is the one that completely penetrates younger rocks and reaches the present-day topographic surface.

The Mogilno salt structure is located about $65 \mathrm{~km}$ east of Poznan (Fig. 1). It is about $30 \mathrm{~km}$ long, and up to $7 \mathrm{~km}$ wide (Fig. 2), elongated in NW-SE direction. The whole structure is underlain by a very thick pillow of the Zechstein salts, reaching 6,000 $\mathrm{m}$ in thickness. In its central zone, a small salt crest rises up. This form is about $8 \mathrm{~km}$ long and up to $1 \mathrm{~km}$ wide and penetrates the Kenozoic rock cover. The salt crest consists of a sequence of PZ-2 (Stassfurt) and, on the flanks, PZ-3 (Leine) and PZ-4 (Aller) formations. The vertical arrangement of layers of the three Zechstein salt cycles is a characteristic feature of this structure. 
The internal structure of the salt body is very complex, including folds with vertical, steeply inclined and overturned axes. The salt crest has a mantle of cap rock resting on the top surface of the salt core. The salt crest is surrounded by the Triassic, Jurassic, and Cretaceous deposits. The thickness of the Mesozoic deposits in the peripheral sinks surrounding the structure reaches as much as 7,000 $\mathrm{m}$ and about $2,000 \mathrm{~m}$ on the periclines of the structure. Some beds lie at a very steep angle, and their slopes vary from $30^{\circ}$ to $65^{\circ}$ in the NE part and reach the angle of $85^{\circ}$ in the $\mathrm{S}$ part. What is a characteristic feature of the Mesozoic deposits in the area of the Mogilno structure is their strongly marked increase in thickness from the centre of the structure to the peripheral sinks, and also numerous hiatuses observed in the elevated parts of the structure. Many transverse, longitudinal, and diagonal dislocations divide the central zone into 15 blocks.

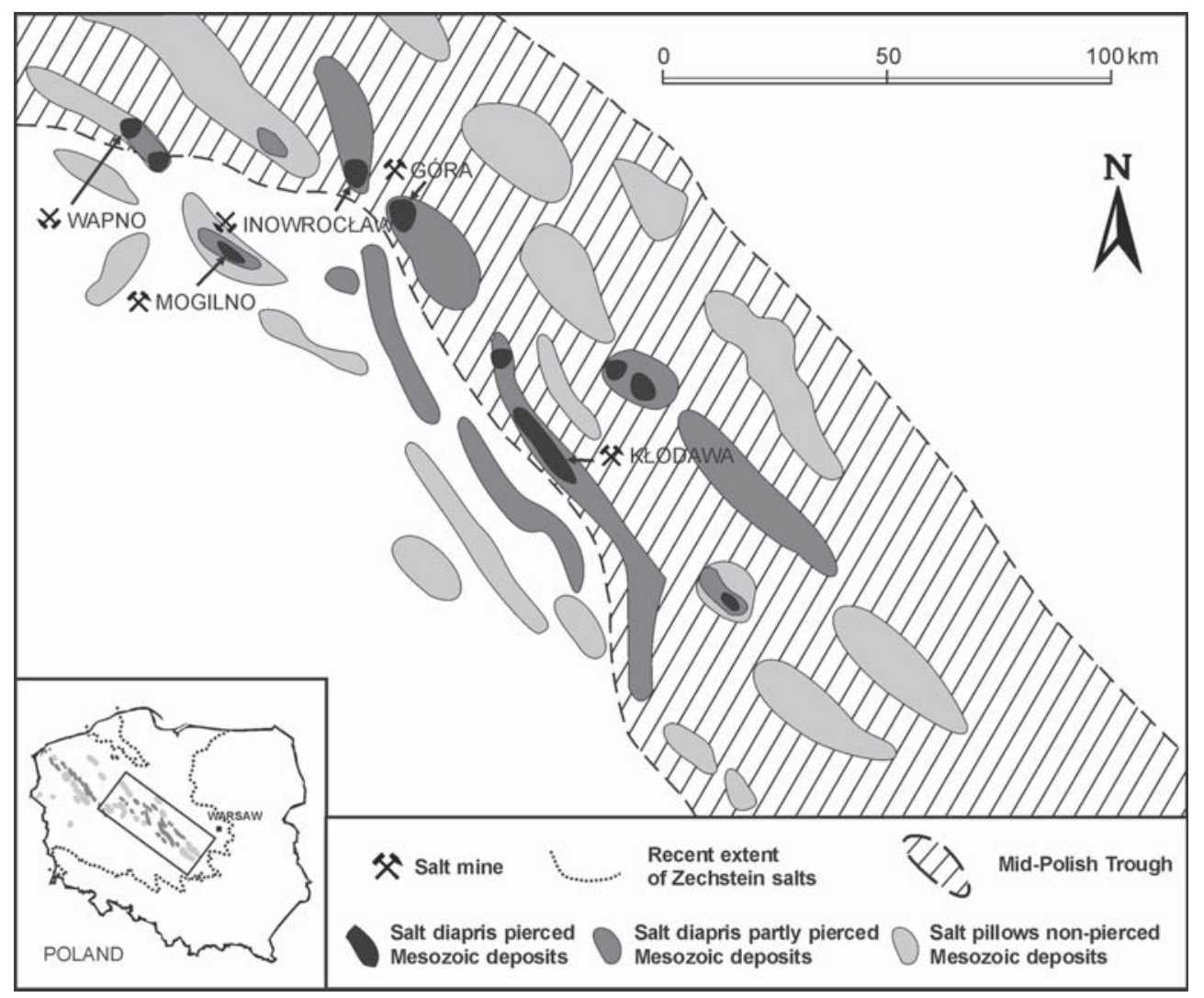

Fig. 1. Distribution of salt structures in the central part of the Mid-Polish Trough (from Garlicki \& Szybist 1986, Dadlez \& Marek 1998, modified by the author)

Fig. 1. Rozmieszczenie struktur solnych w centralnej części bruzdy środkowopolskiej (wg Garlicki \& Szybist 1986, Dadlez \& Marek 1998, zmodyfikowane przez autora) 


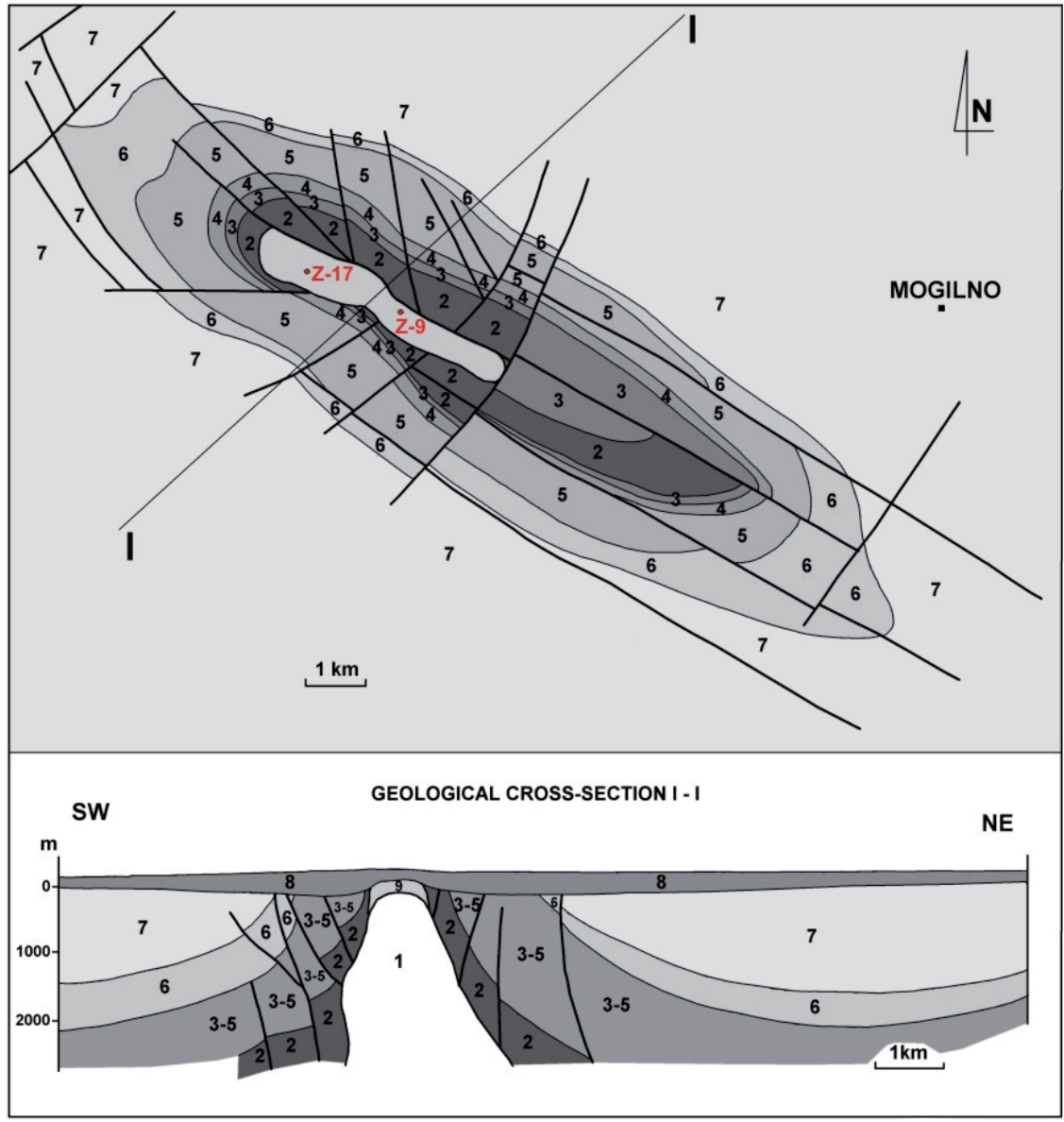

Fig. 2. Geological sketch-map of the Mogilno salt structure, without Cenozoic deposits with geological cross-section (Sokołowski 1966, modified by Wilkosz 2005): 1 - Zechstein salt, 2 - Upper Triassic, 3 - Lower Jurassic, 4 - Middle Jurassic, 5 - Upper Jurassic, 6 - Lower Cretaceous, 7 - Upper Cretaceous, 8 - Cenozoic, 9 - cap rock

Fig. 2. Mapa struktury solnej Mogilno, bez utworów kenozoicznych z przekrojem geologicznym (wg Sokołowski 1966, zmodyfikowana przez Wilkosza 2005): 1 - sole cechsztyńskie, 2 - górny trias, 3 - dolna jura, 4 - środkowa jura, 5 - górna jura, 6 - dolna kreda, 7 - górna kreda, 8 - kenozoik, 9 - czapa gipsowa

The development of the Mogilno salt structure occurred in three stages (Wilkosz 2001, 2006): pillow, diapir and post-diapir. The halo-kinesis was initiated in the Late Muschelkalk/ Early Keuper. The thick salt pillow was formed during Late Triassic to Early Cretaceous. The diapir stage was reached in the Early Cretaceous and continued into Palaeocene and Late Eocene. The post-diapir stage began in the Late Eocene/Early Oligocene and has continued until present day. 
At present, this diapir is the place for gas storage and salt mining operations. The Underground Gas Storage Mogilno Plant is located in the western part of the salt dome. Actually, the gas storage facility has eleven caves, called caverns, located at a depth between $800 \mathrm{~m}$ and $1,600 \mathrm{~m}$. Total gas quantity stored in the salt caverns in the present time is 589.3 million $\mathrm{Nm}^{3}$.

Target investment in the Mogilno II salt deposit provides total activity 20-25 caverns with a total storage capacity will be about 1.8 billion $\mathrm{Nm}^{3}$ of gas (1.2 billion $\mathrm{Nm}^{3}$ operating volume).

\section{METHODS}

Cores from boreholes Z-9 and Z-17 were sampled and profiled during field activities conducted at the KPMG Mogilno on the Mogilno II deposit. Samples weighting 1-5 kg were collected; in total, 91 samples weighting ca. $300 \mathrm{~kg}$. Photographic documentation was made in respect of selected, most interesting core fragments. Tests were conducted at the Laboratory of the Faculty of Geology, Geophysics, and Environmental Protection of AGH in Kraków. after preliminary macroscopic observations, 52 specimens ( 25 from borehole Z-9 and 27 from borehole Z-17) were selected. Microscopic mineralogical and petrographic analyses were made in respect of 52 specimens for polarized permeating light, using a polarizing microscope. The structures and textures of evaporite rocks were determined in accordance with the most recent classification system (Pawlikowski 2008, 2009), with planimetric analysis by the point method, using a ELTINOR semi-automatic integrated counter. In each of the specimens, determinations were made in 500 points. Salt rock cracking was studied. Average crack diameters were measured (in $\mu \mathrm{m}$ ), in respect of the reference line length, and the measurements were conducted in five reference lines in each specimen cut. In salts and zubers, the contents of water insoluble (hardly water soluble) parts were determined, by weight, with an accuracy of about $0.1-0.2 \%$. The inaccuracy is due to slight dissolution of anhydrite in the process of leaching of the samples. Laboratory error limits are determined on the basis of detailed measurements of anhydrite content in a few selected samples of rock salt.

The mineral composition and grain size distribution of water-insoluble (hardly water-soluble) residuum were determined in the ranges of $>2 \mathrm{~mm} ; 2-0.6 \mathrm{~mm} ; 0.6-0.25 \mathrm{~mm}$; $0.25-0.1 \mathrm{~mm}$, and $<0.1 \mathrm{~mm}$. The mineral composition of the smallest fraction and the identification of microcrystalline mono-mineral phases were made by the X-ray diffraction patterns, and recorded at room temperature with a Philips APD X'Pert PW 2030 diffractometer under the following conditions: $\mathrm{CuK} \alpha$ radiation with $\gamma=1.5418 \AA$, accelerating voltage $35 \mathrm{kV}$, beam current 30 management; graphite monochromator, registration velocity $0.02^{\circ}(2 \theta) / 1 \mathrm{~s}$, registration range $2-75^{\circ}(2 \theta)$. The data were analysed using an X-RAYAN computer software and X-ray standards in the form of ICDD files. Indexing was conducted by using a Powder Diffraction computer software. 


\section{RESULTS}

Boreholes Z-9 and Z-17 were drilled through Zechstein salt series formations, composed of a thick rock salt complex, with small potash-magnesium salt, sulphate rock (anhydrites) and evaporite-silicoclastic (zubers and clayey salts) layers (Figs 3, 4).

Four main types of rocks were identified in the cores:

- rock salts,

- potash-magnesium salts,

- zubers and clayey salts,

- anhydrites.

\section{Rock salts}

Rock salts were represented by units of various petrographic types described below.

White and white-grey rock salts belong to the deposits of the PZ-2 cyclothem. They are the dominating rocks in the cores of the two boreholes. They occurred in the whole core interval (Figs 3,4), together with rare, thin shoals of other evaporite rocks, described below. In borehole Z-17, white rock salts occurre from $600 \mathrm{~m}$ to $1,695 \mathrm{~m}$ and above, in the interval of 600-247 m, and these were described on the basis of chip samples. In borehole Z-9, white rock salts occurred from $800 \mathrm{~m}$ to $1,530 \mathrm{~m}$. They are also found in chip samples in shallower depths.

The white and white-greyish colour of those salts are changing in hues, from light white, sometimes transparent, milky white, white and grey-yellowish to grey-whitish and dark grey. Darker hues were associated with the increased proportion of insoluble parts, mainly those dispersed in the salt mass of anhydrite grains. Despite clear macroscopic differences between particular variations, we observed sedimentational continuity (smooth changes between layers), which indicated linear changes of the sedimentation conditions or recrystallization of those formations. Those salt structures were diverse, from fine-blastic (with blasts below $2 \mathrm{~mm}$ ) to coarse-blastic (with blasts above $20 \mathrm{~mm}$ ) or crystalline, with halite crystals of up to $9 \mathrm{~cm}$. Neither of the described salt varieties was characterized by a specific structure, although medium- and coarse-blasts of 2-20 mm were found in the large majority of structures. The halite blasts were usually irregular, and the contact between them was not even. White and white-greyish rock salts mostly displayed directional parallel textures, marked with the lamination of several millimetre anhydrite trails, separated from several to about a dozen of centimetres from each other and a directional layout of elongated halite blasts, complying with shaoling. We also found less frequent stripped directional textures, with clear boundary between coarse-blastic $(10-30 \mathrm{~mm})$ and medium-blastic $(2-10 \mathrm{~mm})$ strips. The texture of salts with yellow-orange hues (the so-called flesh-coloured salt) was poorly compacted. That feature clearly distinguished them from typical white-greyish rock salts, which displayed compacted and massive textures. Some portions of white rock salt did not have clear lamination. 


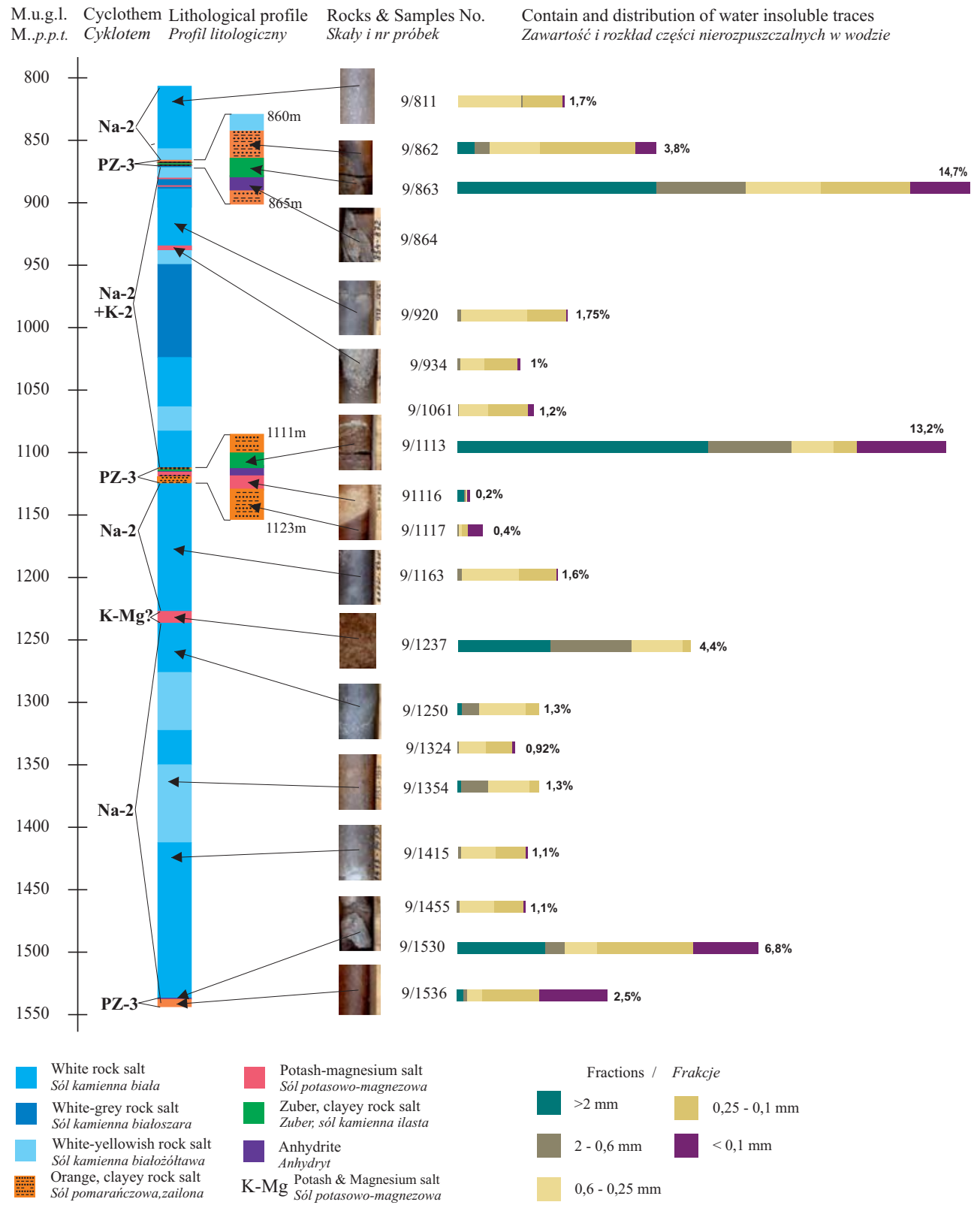

Fig. 3. Lithostratigraphic profile of borehole Z-9. Mogilno Salt Diapir. Mogilno II deposit

Fig. 3. Profil litostratygraficzny otworu Z-9. Wysad solny Mogilno, złoże Mogilno II 
M.u.g.1. Cyclothem Lithological profile Rocks \& Samples No. Contain and distribution of water insoluble traces M..p.p.t. Cyklotem Profil litologiczny Skaly i nr próbek Zawartość i rozkład części nierozpuszczalnych w wodzie

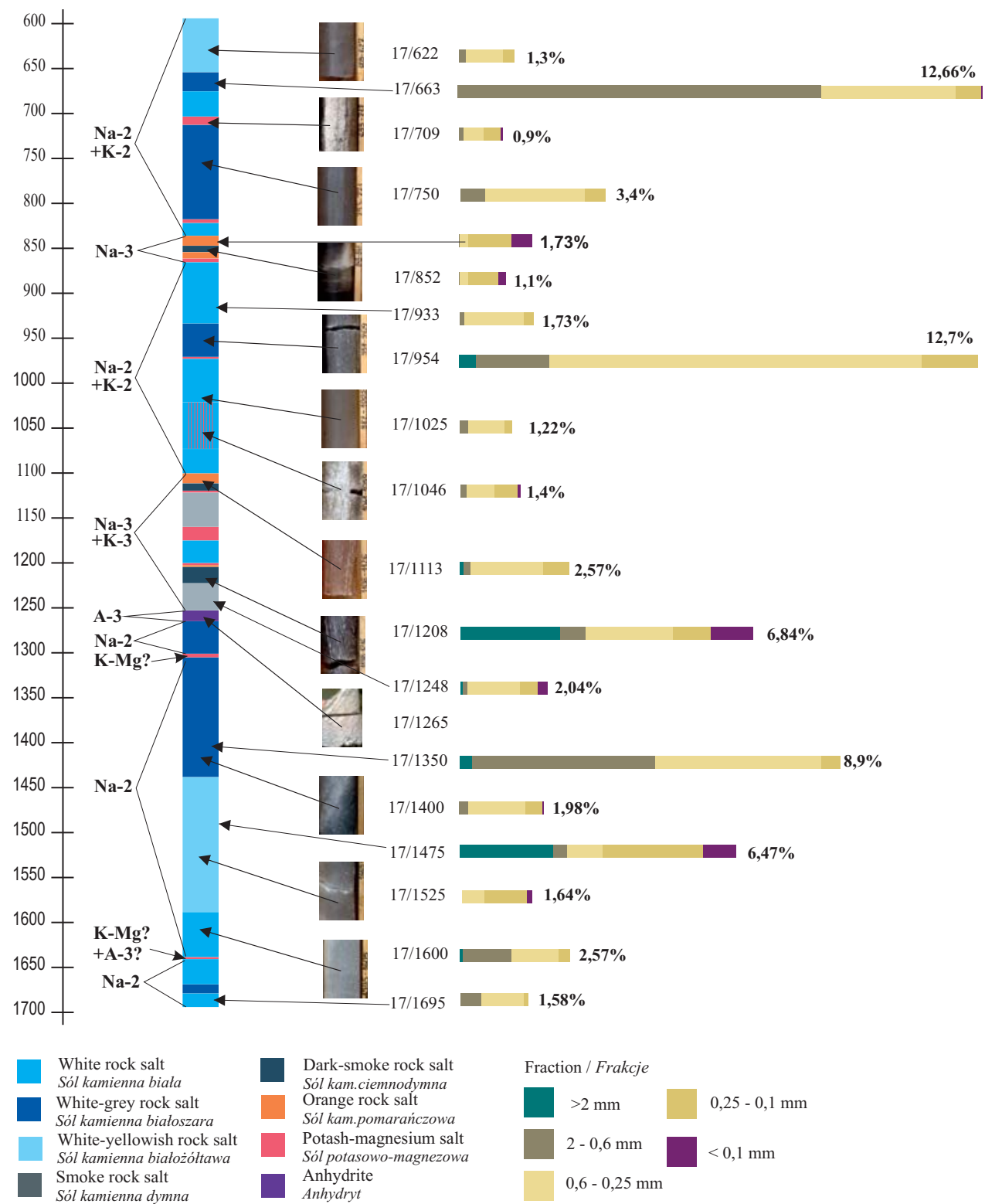

Fig. 4. Lithostratigraphic profile of borehole Z-17. Mogilno Salt Diapir. Mogilno II deposit

Fig. 4. Profil litostratygraficzny otworu Z-17. Wysad solny Mogilno, złoże Mogilno II 
Anhydrite occurred in a dispersed suspension form, which was not seen macroscopically in the salt mass. The mineral admixture contents, which were poorly soluble in water, were found in those rock salts in the proportions from $0.9 \%$ to $12.7 \%$ by weight (Tabs 1,2$)$, although the highest contents were found only in two layers of dark grey rock salt of borehole $\mathrm{Z}-17$, at the depths of 663-673 m and $954 \mathrm{~m}$. In the large majority of white and white-greyish rock salts, the contents of water-insoluble residue reached 1-2\%. The granulometric distribution was typical for that of older rock salts. The majority of grains ranged from hundredths of a millimetre to several millimetres, although the large majority of ca. 80-90\% was situated in the $0.1-0.6 \mathrm{~mm}$ fraction, which was characteristic for those salts and distinguished them from the younger layer rock salts (Tabs 1, 2, Fig. 10). Monocrystalline anhydrite, constituting more than $99 \%$ of the residual mass, was the main component of the insoluble parts. Trace quantities of quartz and dolomite were identified. Anhydrite created euhedrally shaped crystals in the form of plates, poles, or slats, with diverse morphology and dimensions. They were mainly concentrated in the inter-granular spaces, creating wreath-like concentrations around halite blasts (Fig. 5A), and in anhydrite trails and laminas determining the so-called annual growths (Fig. 5B). Anhydrite inside halite blasts was rarely encountered. Quartz occurred in the form of spherical, polycrystalline, euhedral compounds, transparent crystals, or the so-called quartz roses, with the diameter of up to $1.5 \mathrm{~mm}$. Dolomite also created euhedral crystal compounds made up of several specimens, with honey-brown colour and the dimensions of up to $1 \mathrm{~mm}$.

\section{Table (Tabela) 1}

Grain size distribution of water-insoluble residue extracted from rock salts of borehole Z-9

\section{Rozkład granulometryczny czesści nierozpuszczalnych w wodzie wydzielonych} ze skat solnych otworu Z-9

\begin{tabular}{|c|c|c|c|c|c|c|c|}
\hline \multirow{2}{*}{$\begin{array}{l}\text { Sample } \\
\text { No. } \\
\text { Numer } \\
\text { próbki }\end{array}$} & \multirow[b]{2}{*}{$\begin{array}{l}\text { Type of rock } \\
\text { Rodzaj skaty }\end{array}$} & \multirow{2}{*}{$\begin{array}{l}\text { Insol. Res. } \\
\text { [wt. \%] } \\
\text { Cz. nierozp. } \\
\text { [\% wag.] }\end{array}$} & \multicolumn{5}{|c|}{ Fraction [wt. \%], Frakcje [\% wag.] } \\
\hline & & & $>2 \mathrm{~mm}$ & $\begin{array}{c}2.0- \\
0.6 \mathrm{~mm}\end{array}$ & $\begin{array}{c}0.6- \\
0.25 \mathrm{~mm}\end{array}$ & $\begin{array}{c}0.25- \\
0.1 \mathrm{~mm}\end{array}$ & $\begin{array}{l}<0.1 \\
\mathrm{~mm}\end{array}$ \\
\hline 811 & $\begin{array}{c}\text { white rock salt } \\
\text { sól kamienna biała }\end{array}$ & 1.7 & 0 & 2.4 & 58.5 & 37.1 & 2 \\
\hline 860 & $\begin{array}{c}\text { white-yellow salt } \\
\text { sól kamienna białozótta }\end{array}$ & 0.9 & 0 & 0 & 40.8 & 56.7 & 2.5 \\
\hline 862 & $\begin{array}{l}\text { dark-orange rock salt } \\
\text { sól kamienna } \\
\text { ciemnopomarańczowa }\end{array}$ & 3.8 & 8.4 & 7.8 & 25 & 48.4 & 10.4 \\
\hline 863 & $\begin{array}{l}\text { brown zuber } \\
\text { zuber brunatny }\end{array}$ & 14.7 & 38.8 & 17.5 & 14.6 & 17.5 & 11.6 \\
\hline 883 & $\begin{array}{c}\text { white rock salt } \\
\text { sól kamienna biała }\end{array}$ & 1.7 & 0 & 2.5 & 57.8 & 38.3 & 1.4 \\
\hline 920 & $\begin{array}{c}\text { white rock salt } \\
\text { sól kamienna biała }\end{array}$ & 1.7 & 0 & 3.2 & 59.9 & 35.7 & 1.2 \\
\hline 934 & $\begin{array}{c}\text { potash-magnesium salt } \\
\text { sól potasowo-magnezowa }\end{array}$ & 1 & 0 & 5.1 & 37.1 & 53.2 & 4.6 \\
\hline
\end{tabular}


Table (Tabela) 1 cont. / cd.

\begin{tabular}{|c|c|c|c|c|c|c|c|}
\hline \multirow{2}{*}{$\begin{array}{l}\text { Sample } \\
\text { No. } \\
\text { Numer } \\
\text { próbki }\end{array}$} & \multirow[b]{2}{*}{$\begin{array}{l}\text { Type of rock } \\
\text { Rodzaj skaty }\end{array}$} & \multirow{2}{*}{$\begin{array}{l}\text { Insol. Res. } \\
\text { [wt. \%] } \\
\text { Cz. nierozp. } \\
\text { [\% wag.] }\end{array}$} & \multicolumn{5}{|c|}{ Fraction [wt. \%], Frakcje [\% wag.] } \\
\hline & & & $>2 \mathrm{~mm}$ & $\begin{array}{c}2.0- \\
0.6 \mathrm{~mm}\end{array}$ & $\begin{array}{c}0.6- \\
0.25 \mathrm{~mm}\end{array}$ & $\begin{array}{c}0.25- \\
0.1 \mathrm{~mm}\end{array}$ & $\begin{array}{l}<0.1 \\
\mathrm{~mm}\end{array}$ \\
\hline 970 & $\begin{array}{l}\text { white-greyish rock salt } \\
\text { sól kamienna białoszara }\end{array}$ & 1.4 & 0 & 2.8 & 37.7 & 53.9 & 5.6 \\
\hline 1021 & $\begin{array}{c}\text { white rock salt } \\
\text { sól kamienna biała }\end{array}$ & 1.2 & 0 & 2.3 & 57.4 & 40.3 & 0 \\
\hline 1061 & $\begin{array}{c}\text { white rock salt } \\
\text { sól kamienna biała }\end{array}$ & 1.2 & 0 & 0.8 & 38.8 & 52.6 & 7.8 \\
\hline 1113 & $\begin{array}{c}\text { brown zuber } \\
\text { zuber brunatny }\end{array}$ & 13.2 & 51.4 & 17 & 8.6 & 4.7 & 18.2 \\
\hline 1116 & $\begin{array}{c}\text { potash-magnesium salt } \\
\text { sól potasowo-magnezowa }\end{array}$ & 0.2 & 0 & 16.3 & 69.7 & 14 & 0 \\
\hline 1117 & $\begin{array}{l}\text { dark-orange rock salt } \\
\text { sól kamienna } \\
\text { ciemnopomarańczowa }\end{array}$ & 0.4 & 0 & 6.5 & 11.7 & 24.8 & 57 \\
\hline 1163 & $\begin{array}{c}\text { white rock salt } \\
\text { sól kamienna biała }\end{array}$ & 1.6 & 0 & 4.6 & 56.5 & 37.7 & 1.2 \\
\hline 1237 & $\begin{array}{c}\text { potash salt } \\
\text { sól potasowa }\end{array}$ & 4.4 & 39.7 & 35.1 & 21.8 & 3.4 & 0 \\
\hline 1250 & $\begin{array}{l}\text { white rock salt } \\
\text { sól kamienna biała }\end{array}$ & 1.3 & 5.4 & 21.8 & 56.5 & 16.3 & 0 \\
\hline 1277 & $\begin{array}{c}\text { white-yellow salt } \\
\text { sól kamienna białożótta }\end{array}$ & 1.3 & 0 & 3.9 & 34.2 & 50.6 & 11.3 \\
\hline 1324 & $\begin{array}{c}\text { white rock salt } \\
\text { sól kamienna biała }\end{array}$ & 1.3 & 0 & 3.6 & 47.9 & 43.6 & 4.9 \\
\hline 1352 & $\begin{array}{c}\text { white-grey rock salt } \\
\text { sól kamienna biatoszara }\end{array}$ & 1.1 & 0 & 4.9 & 49.3 & 43.1 & 2.7 \\
\hline 1354 & $\begin{array}{c}\text { white-yellow salt } \\
\text { sól kamienna białożótta }\end{array}$ & 1.3 & 0 & 3.2 & 36.8 & 51.6 & 8.4 \\
\hline 1415 & $\begin{array}{c}\text { white-grey rock salt } \\
\text { sól kamienna białoszara }\end{array}$ & 1.1 & 0 & 3.4 & 52.1 & 41.3 & 3.2 \\
\hline 1455 & $\begin{array}{c}\text { white-grey rock salt } \\
\text { sól kamienna białoszara }\end{array}$ & 1.1 & 0 & 3.7 & 48.6 & 45.1 & 2.6 \\
\hline 1500 & $\begin{array}{c}\text { white rock salt } \\
\text { sól kamienna biała }\end{array}$ & 1.2 & 0 & 4.8 & 58.7 & 35.3 & 1.2 \\
\hline 1530 & $\begin{array}{l}\text { anhydrite } \\
\text { anhydryt }\end{array}$ & 6.8 & 29 & 6.7 & 10.7 & 32 & 21.6 \\
\hline 1536 & $\begin{array}{l}\text { dark-orange rock salt } \\
\text { sól kamienna } \\
\text { ciemnopomarańczowa }\end{array}$ & 2.5 & 4.4 & 2.6 & 10.2 & 37.9 & 44.9 \\
\hline
\end{tabular}




\section{Table (Tabela) 2}

Grain size distribution of water-insoluble residuum extracted from rock salts of borehole Z-17 Rozkład granulometryczny części nierozpuszczalnych w wodzie wydzielonych ze skat solnych otworu Z-17

\begin{tabular}{|c|c|c|c|c|c|c|c|}
\hline \multirow{2}{*}{$\begin{array}{l}\text { Sample } \\
\text { No. } \\
\text { Numer } \\
\text { próbki }\end{array}$} & \multirow[b]{2}{*}{$\begin{array}{l}\text { Type of rock } \\
\text { Rodzaj skaty }\end{array}$} & \multirow{2}{*}{$\begin{array}{l}\text { Insol. Res. } \\
\text { [wt. \%] } \\
\text { Cz. nierozp. } \\
\text { [\% wag.] }\end{array}$} & \multicolumn{5}{|c|}{ Fraction [wt. \%], Frakcje [\% wag.] } \\
\hline & & & $>2 \mathrm{~mm}$ & $\begin{array}{c}2.0- \\
0.6 \mathrm{~mm}\end{array}$ & $\begin{array}{l}0.6- \\
0.25 \\
\mathrm{~mm}\end{array}$ & $\begin{array}{c}0.25- \\
0.1 \mathrm{~mm}\end{array}$ & $\begin{array}{l}<0.1 \\
\mathrm{~mm}\end{array}$ \\
\hline 622 & $\begin{array}{c}\text { white rock salt } \\
\text { sól kamienna biała }\end{array}$ & 1.3 & 0 & 11.8 & 67.9 & 20.3 & 0 \\
\hline 663 & $\begin{array}{c}\text { dark-grey rock salt } \\
\text { sól kamienna ciemnoszara }\end{array}$ & 12.66 & 0 & 70.1 & 24.9 & 4.8 & 0.2 \\
\hline 709 & $\begin{array}{c}\text { potash-Magnesium salt } \\
\text { sól potasowo-magnezowa }\end{array}$ & 0.9 & 0 & 8.9 & 29.4 & 52.8 & 8.9 \\
\hline 750 & $\begin{array}{l}\text { white-Grey rock salt } \\
\text { sól kamienna białoszara }\end{array}$ & 3.4 & 0 & 17.1 & 68.8 & 14.1 & 0 \\
\hline 818 & $\begin{array}{c}\text { white rock salt } \\
\text { sól kamienna biała }\end{array}$ & 2.9 & 4.5 & 8.3 & 56.7 & 30.5 & 0 \\
\hline 827 & $\begin{array}{l}\text { potash-magnesium salt } \\
\text { sól potasowo-magnezowa }\end{array}$ & 0.14 & 0 & 8.3 & 44.5 & 38.1 & 9.1 \\
\hline 841 & $\begin{array}{l}\text { orange rock salt } \\
\text { sól kamienna } \\
\text { pomarańczowa }\end{array}$ & 1.73 & 0 & 1.9 & 11.2 & 58.8 & 28.1 \\
\hline 852 & $\begin{array}{l}\text { smoke rock salt } \\
\text { sól kamienna dymna }\end{array}$ & 1.1 & 0 & 3.2 & 18.2 & 62.4 & 16.2 \\
\hline 933 & $\begin{array}{c}\text { white rock salt } \\
\text { sól kamienna biała }\end{array}$ & 1.73 & 0 & 6.5 & 80.5 & 13 & 0 \\
\hline 954 & $\begin{array}{l}\text { sark-grey rock salt } \\
\text { sól kamienna ciemnoszara }\end{array}$ & 12.7 & 3.3 & 14.2 & 71.7 & 10.8 & 0 \\
\hline 1025 & $\begin{array}{l}\text { white rock salt } \\
\text { sól kamienna biata }\end{array}$ & 1.22 & 0 & 16.3 & 69.7 & 14 & 0 \\
\hline 1046 & $\begin{array}{c}\text { potash-magnesium salt } \\
\text { sól potasowo-magnezowa }\end{array}$ & 1.4 & 0 & 10.5 & 45.9 & 38.7 & 4.9 \\
\hline 1113 & $\begin{array}{l}\text { orange rock salt } \\
\text { sól kamienna } \\
\text { pomarańczowa }\end{array}$ & 2.57 & 3.3 & 6.3 & 66.5 & 23.9 & 0 \\
\hline 1150 & $\begin{array}{c}\text { smoke rock salt } \\
\text { sól kamienna dymna }\end{array}$ & 1.8 & 0 & 1.6 & 23 & 66.5 & 8.9 \\
\hline 1175 & $\begin{array}{l}\text { potash-magnesium salt } \\
\text { sól potasowo-magnezowa }\end{array}$ & 0.7 & 0 & 7.3 & 23.9 & 57.1 & 11.7 \\
\hline
\end{tabular}


Table (Tabela) 2 cont. / cd.

\begin{tabular}{|c|c|c|c|c|c|c|c|}
\hline \multirow{2}{*}{$\begin{array}{l}\text { Sample } \\
\text { No. } \\
\text { Numer } \\
\text { próbki }\end{array}$} & \multirow[b]{2}{*}{$\begin{array}{l}\text { Type of rock } \\
\text { Rodzaj skaty }\end{array}$} & \multirow{2}{*}{$\begin{array}{c}\text { Insol. Res. } \\
\text { [wt. \%] } \\
\text { Cz. nierozp. } \\
\text { [\% wag.] }\end{array}$} & \multicolumn{5}{|c|}{ Fraction [wt. \%], Frakcje [\% wag.] } \\
\hline & & & $>2 \mathrm{~mm}$ & $\begin{array}{c}2.0- \\
0.6 \mathrm{~mm}\end{array}$ & $\begin{array}{l}0.6- \\
0.25 \\
\mathrm{~mm}\end{array}$ & $\begin{array}{c}0.25- \\
0.1 \mathrm{~mm}\end{array}$ & $\begin{array}{l}<0.1 \\
\mathrm{~mm}\end{array}$ \\
\hline 1203 & $\begin{array}{l}\text { potash-magnesium salt } \\
\text { sól potasowo-magnezowa }\end{array}$ & 3.5 & 44 & 35.6 & 17.4 & 3 & 0 \\
\hline 1208 & $\begin{array}{c}\text { dark-smoke rock salt } \\
\text { sól kamienna } \\
\text { ciemnodymna }\end{array}$ & 6.84 & 33.8 & 8.9 & 30 & 12.7 & 14.6 \\
\hline 1248 & $\begin{array}{c}\text { smoke rock salt } \\
\text { sól kamienna dymna }\end{array}$ & 2.04 & 2.4 & 5.2 & 36.2 & 44.8 & 11.4 \\
\hline 1303 & $\begin{array}{l}\text { white-grey rock salt } \\
\text { sól kamienna białoszara }\end{array}$ & 2.12 & 0 & 18.8 & 66 & 15.2 & 0 \\
\hline 1350 & $\begin{array}{l}\text { white-grey rock salt } \\
\text { sól kamienna białoszara }\end{array}$ & 8.9 & 3.1 & 48.4 & 43.5 & 5 & 0 \\
\hline 1400 & $\begin{array}{c}\text { white-grey rock salt } \\
\text { sól kamienna białoszara }\end{array}$ & 1.98 & 0 & 11.7 & 70 & 17.3 & 1 \\
\hline 1475 & $\begin{array}{l}\text { white-grey rock salt } \\
\text { sól kamienna białoszara }\end{array}$ & 6.47 & 33.9 & 5.1 & 12.7 & 36.4 & 11.9 \\
\hline 1525 & $\begin{array}{l}\text { white-yellow rock salt } \\
\text { sól kamienna białożótta }\end{array}$ & 1.64 & 0 & 0.5 & 31.6 & 60.5 & 7.4 \\
\hline 1600 & $\begin{array}{c}\text { white rock salt } \\
\text { sól kamienna biała }\end{array}$ & 2.57 & 3.2 & 43.7 & 40.2 & 12.9 & 0 \\
\hline 1695 & $\begin{array}{c}\text { white rock salt } \\
\text { sól kamienna biała }\end{array}$ & 1.58 & 0 & 30.1 & 63.9 & 6 & 0 \\
\hline
\end{tabular}

Fig. 5. A) Halite blasts surrounded by anhydrite blasts, Pol. X. B) Linear concentration of anhydrite blasts in anhydrite lamina, Pol. X. C) Microscopic image of kieseritic sylvinite: twinned kieserite blasts among halite and sylvine blasts, Pol. X. D) Contacts between halite, sylvine and kieserite blasts, Pol. 1 . E) Hydrocarbon inclusions between halite blasts, Pol. 1. F) Fragment of carbonate-gypsum clast, with the admixtures of allogenic quartz and pyrite, Pol. X. Syl - Sylvine, Kiz - Kieserite, W - Carbonates,

$$
\text { G - Gypsum, Q - Quartz, P - Pyrite }
$$

Fig. 5. A) Blasty halitu otoczone blastami anhydrytu, Pol. X. B) Liniowa koncentracja blastów anhydrytu w laminie anhydrytowej, Pol. X. C) Obraz mikroskopowy sylwinitu kizerytowego - zbliźniaczone blasty kizerytu wśród blastów halitu i sylwinu, Pol. X. D) Kontakt blastów halitu, sylwinu i kizerytu, Pol. 1. E) Inkluzje węglowodorów pomiędzy blastami halitu, Pol. 1. F) Fragment klastu węglanowogipsowego z domieszką kwarcu allogenicznego i pirytu, Pol. X. Syl - sylwin, Kiz - kizeryt, W - węglany, G - gips, Q - kwarc, P - piryt 
Research results included determination of a common complex of such salt rock features as: white and white-greyish colour, lack of clay minerals and potash-magnesium salt admixtures, coarse granulation of insoluble parts, and good recrystallization of anhydrite (exclusively euhedral shapes), which were characteristic for the rock salts of cyclothem PZ-2.
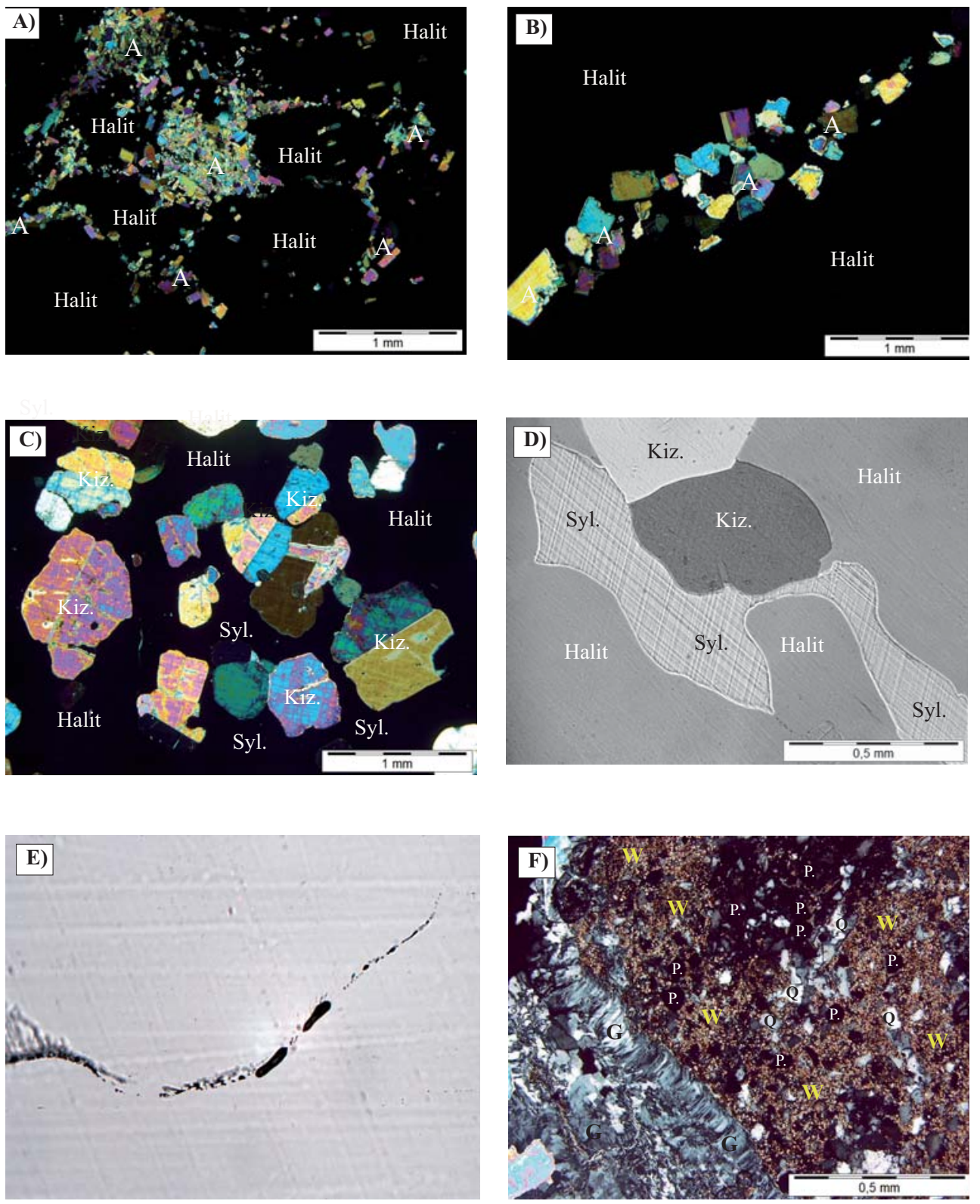
Grey-orange salts representing the evaporites of cyclothem PZ-3. Various degrees of contamination with clay and sulphate minerals (mainly anhydrite) caused changes of salt colouring, from light to dark orange. Red, pink or orange halite colours were caused by the presence of microcrystalline or ferrous oxide and hydroxide inclusions. Salts of that type were identified in borehole Z-9, in three depth intervals of 860-865 m, 1,111-1,123 m, and 1,530-1,536 m (Fig. 3), although in case of the first two intervals, the same folded layer was drilled through twice. In the bottom interval $(1,530-1,536 \mathrm{~m})$, such a repetition is also possible, but it is hard to identify owing to the completion of drilling works and lack of core data from lower layers. The occurrence of grey-orange salts was closely associated with the vicinity of zubers, anhydrites and potash-magnesium salts, with which the former created natural, strongly reduced evaporite sedimentation sequence of cyclothem PZ-3 (Fig. 3). Those salts were usually laminated with thin, light anhydrite laminas (1-2 mm) and dark trails of carbonate-clay substance. On the core surface, we could observe leached cracks and nests emptied by potash-magnesium salts. The structure of those salts was mixed and unevenly blastic. Pure pink salts were medium-blastic ( $2-8 \mathrm{~mm}$ blasts), or coarse-blastic close to anhydrite laminas and dark clay-carbonate trails. The diameters of some blasts reached $20 \mathrm{~mm}$. Large halite blasts, visible on the core surface, were colourless, transparent, and they were clearly distinguished on the rock background. They often contained ingrowths of smaller red halite blasts, with the diameter of 1-2 mm, sometimes wrongly interpreted to be polyhalite. In the spaces between grains, we could see hydrocarbon trails and inclusions. The texture of the rock was layered in parallel, distinguished by light anhydrite laminas and sometimes, and in some areas with directional layout of elongated halite blasts, laid in parallel to layers. Insoluble part contents ranged from $2.5 \%$ to $3.8 \%$. Exceptionally in some layers, the contents dropped to $0.4 \%$ (sample $9 / 1117$ ). In grey-orange salts, fine grains of insoluble parts were clearly visible. The proportion of $<0.25 \mathrm{~mm}$ fractions was from $58.8 \%$ to $82.8 \%$ (Tab. 1, Fig. 10). The waterinsoluble residue was dominated by anhydrite, found in the form of polycrystalline aggregates in thicker fractions of $>0.6 \mathrm{~mm}$, rarely in the form of mono-crystals, and in smaller fractions of $<0.6 \mathrm{~mm}$, in the form of flat, irregular plates, mostly circular or oval, and sometimes as poles and slats. The majority of crystals were shaped subhedrally. The upper and lower crystal surfaces were finished flat, evenly, without characteristic barbs. They were slightly transparent. Side walls of crystals were transparent, with longitudinal strips. Quartz occurred in the authigenic form, with euhedrally shaped crystals of the size of $0.1-1.2 \mathrm{~mm}$. Large crystals were grey-yellow, poorly transparent, often slightly etched on the column and pyramid walls. Smaller crystals were transparent, colourless, often with pink hue. Quartz contents usually did not exceed $1 \%$ in insoluble parts. Exceptionally, the proportion increased to $20 \%$ in dark orange salt from the depth of $1,117 \mathrm{~m}$ of borehole Z-9. Trace quantities of the ppm order displayed the presence of boracite, pyrite, magnezite, chlorite, and talk.

The complex of the above presented such typical features of those salts as: proximity of zubers and potash-magnesium salts, orange-pinkish colour, domination of smaller fractions in insoluble parts, poor anhydrite recrystallization (lack of euhedral crystals), and rich proportion of accessory minerals, especially clay and borate ones, as characteristic for the rock salt cyclothem PZ-3. 
Orange and smoky salts were evaporites of cyclothem PZ-3, deposited above main anhydrite (A-3). Mineralogical and petrographic studies proved that despite obvious colour difference, the salts were adjacent units of a natural sedimentation shift, and their orange colour was not stratigraphically identical with the grey-orange colour of the salts described before. Such a lithostratigraphic sequence has been documented for the first time in the Polish Zechstein and it has a close counterpart in the German Zechstein salt formations of the Hannover period (Schwadensalz of the top sub-cyclothem PZ-3). In the Mogilno diapir, that type of salt was found in borehole Z-17, at the depths of ca. 841-852 m, 1,113-1,150 m, and $1,208-1,248 \mathrm{~m}$, although we were dealing with a sequence of layers drilled through twice in the case of the first two intervals. Those salts represented two petrographic types of pure rock salts: orange, with various degrees of Fe colouration, and smoky salts, with various degrees of transparency. The smoky hues of those rocks are hard to explain clearly on the basis of previous research. The reason of that can be micro-inclusions of hydrocarbons, creating linear concentrations between halite blasts, observed in microscopic specimens (Fig. 5E). However, we should mention here that smoky and dark smoky salts do not produce even a minimum of bituminous aroma when crushed or dissolved. The smoky hue can also be caused by a small admixture of kieserite and sylvine, found in a dispersed form in those salts (e.g. when rock salt came to contact with sylvine in samples $17 / 705$ and 17/827, containing sylvine and kieserite, it also became dark smoky). Possible physical and chemical influence of those minerals on the smoky hue of rock salt will be the object of further studies.

The structure of smoky and orange salts was small-, medium-, and coarse-blastic. Blasts were mostly isometric, with a tendency to elongate. The directional and parallel texture was presented by thin anhydrite laminas and trails. Smoky salts were very dark (sample 17/1208) and poorly transparent. When seen against light in a thin $3 \mathrm{~cm}$ disc, their colour was honeygrey, with dense lamination of anhydrite trails every $2-3 \mathrm{~mm}$. In the bottom section, the salt smoothly switched into smoky, lighter and transparent salt. The insoluble part contents ranged from $0.54 \%$ (sample $17 / 852$ - light smoky salt) to $6.84 \%$ (sample $17 / 1208$ - dark smoky salt). What was a characteristic feature of those rock salts was fine granulation of insoluble residue. About $87 \%$ of insoluble material had the dimension of less than $0.25 \mathrm{~mm}$ (e.g. samples 17/841, 852, and 1150) (Tab. 2, Fig. 10). Anhydrite was the main component of insoluble parts, constituting more than $99 \%$ of residue. Crystal anhydrite, in the form of cubes, poles, and plates was characterized by poorer subhedral formation, creating the impression of cracked and crushed forms. Anhydrite was located in the spaces between halite blasts and within blasts. In addition to the above-specified minerals, another characteristic feature of all the smoky and orange salt formations, as well as the adjacent potash-magnesium salts, was the presence of small quantities of euhedral crystal boracite, of the sort of tetrahedral ones (ca. 1\% in insoluble residue).

The sequence (from bottom to ceiling): smoky salt - orange salt - potash-magnesium salt seemed to be a fragment of a natural, undisturbed (tectonically) sedimentation sequence. Information obtained from the salt studies, such as: close occurrence of main anhydrite at the bottom, orange and smoky hues, poor anhydrite recrystallization (majority of subhedral crystals), and sylvine, kieserite, and boracite admixtures indicated the identification of smoky and orange salts with the sediments of the lower or middle part of cyclothem PZ-3. 


\section{Potash-magnesium salts}

In the cores of boreholes Z-9 and Z-17, several thin layers of potash-magnesium salts were found (Figs 3, 4). Based on the mineralogical-petrographic analysis results, two genetic types of those salts were distinguished:

- kieseritic sylvinite,

- kieserite-free potash salt.

Kieseritic sylvinite occured in the form of thin laminas and layers, several millimetres to several dozens of centimetres thick. In borehole Z-9, they were found at the depths of $872 \mathrm{~m}$, $884 \mathrm{~m}, 934 \mathrm{~m}$, and 1,116 m. In borehole Z-17, sylvine layers were identified at the depths of $710 \mathrm{~m}, 827 \mathrm{~m}, 976 \mathrm{~m}, 1,046 \mathrm{~m}, 1,175 \mathrm{~m}, 1,203 \mathrm{~m}$, and 1,642 m. Outside the cores, kieseritic sylvinit were covered with a several millimetre thick layer of white-greyish weathered coat composed of halite and epsomite. Within a fresh fracture, inside a core, the rock was orangewhite-greyish, with a bitter-salty taste. It was composed of three main minerals occurring in changing proportions: halite (30-70\%), sylvine (10-35\%), and kieserite (10-30\%). The results of mineral composition analysis of selected samples are presented in tables 3 and 4.

Kieseritic sylvinite had a mixed structure, from fine- to coarse-blastic. Halite and sylvine blasts had the sizes of several millimetres; the borders between blasts were bay shaped, while sylvine, with weaker force of blastesis, was clearly anhedral and it occurred in the spaces between halite blasts. Kieserite created subhedral, isometric blasts, mostly with individual twinning (the so-called doubles), usually with the diameter of $0.1-0.5 \mathrm{~mm}$, with clear blastic strength from halite and sylvine. The microscopic image of those relationships are shown in figure 5C, 5D. In addition, the salt mass contained single blasts of red halite, with the diameter of up to $10 \mathrm{~mm}$, white-greyish 1-2 $\mathrm{cm}$ fine-blastic kieserite aggregates, several millimetre large carbonate clasts, incrusted with detritic quartz and pyrite. Secondary fibrous gypsum occurred on the clast edges (Fig. 5F).

$\mathrm{X}$-ray analysis of raw samples confirmed the presence of halite, sylvine, kieserite and kainite (Fig. 6A). In some samples (9/884 and 17/1203), the presence of polyhalite was identified in the residue after chloride leaching. No reflexes of other potash chloride minerals were found, e.g. carnallite. The contents of insoluble parts were ranging from $0.14 \%$ to $3.5 \%$ (Tabs 1,2). They were the lowest values in both profiles, caused by a minimum proportion of monocrystalline anhydrite. In the insoluble residue obtained after dissolution in hot water, macroscopic observations (under a binocular magnifier) revealed trace contents of euhedral crystals of pyrite and calcite. X-ray analysis of the finest fractions $(<0.1 \mathrm{~mm})$ indicated the presence of chlorite, talk, calcite and magnesite (Fig. 6B).

Kieserite-free potash salt occurred only in borehole Z-9, at the depth of ca. 1,237 m. Owing to strong core slaking, it was hard to establish the thickness and course of the layer. Based on the debris left in the crate and salt rock fragments, we could determine thickness to be approximately about several dozens of centimetres. All chloride potash salts were leached out. The remaining rock salt was white-greyish, with orange hue. It was medium- and coarseblastic $(0.5-2 \mathrm{~cm}$ blasts). In leached cracks, the traces (coating) of microcrystalline hematite were found, or the so-called hematite cream. 


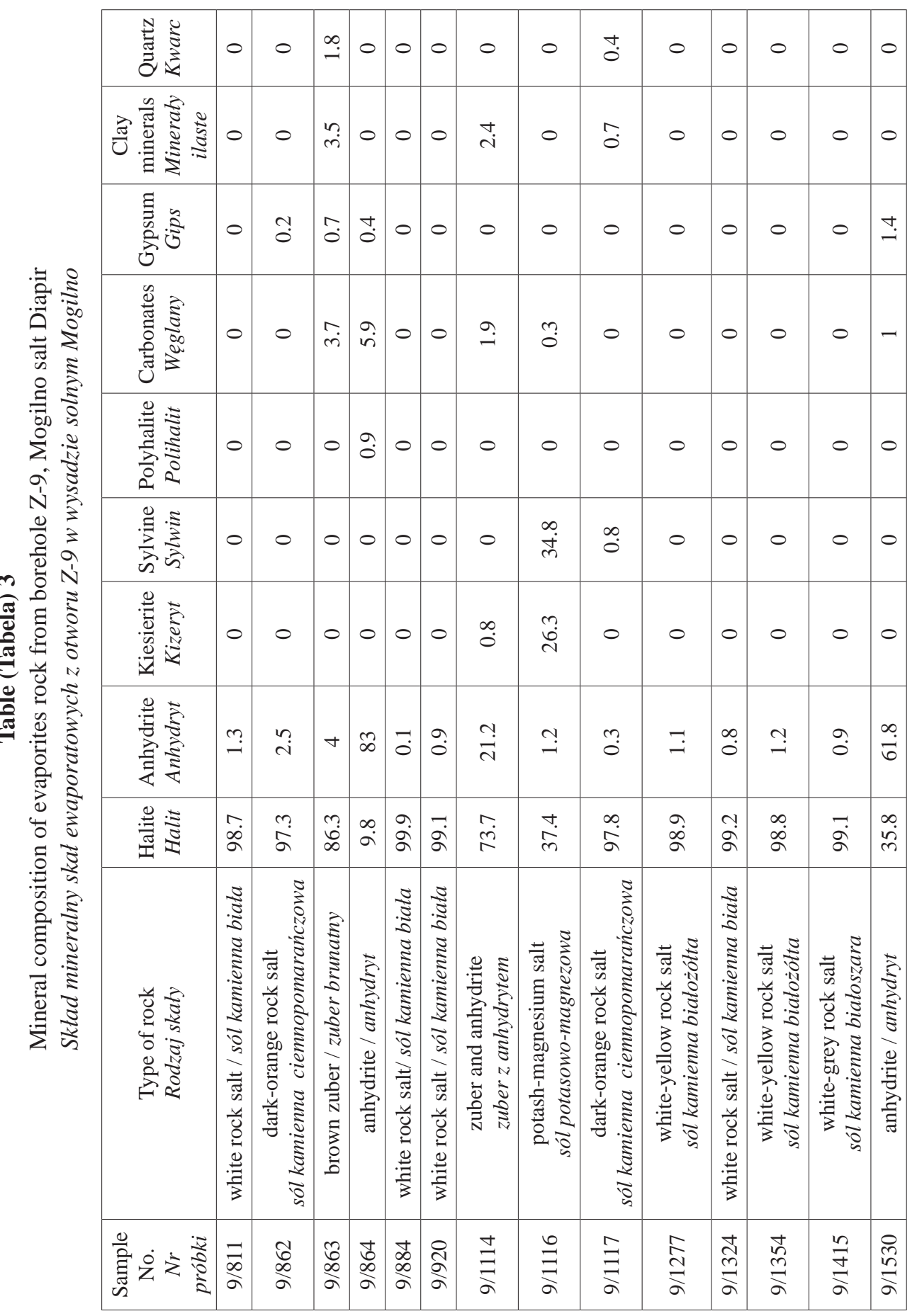




\begin{tabular}{|c|c|c|c|c|c|c|c|c|c|c|c|}
\hline \multirow{9}{*}{ 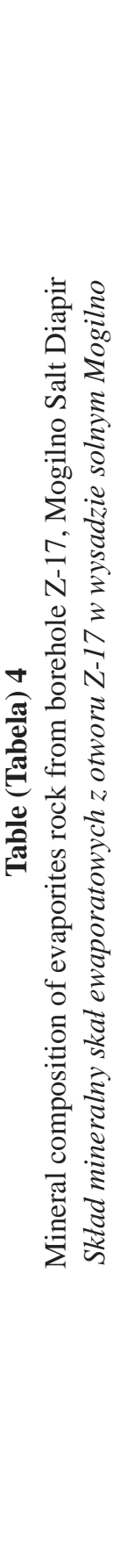 } & 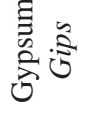 & 0 & 0 & $\stackrel{\infty}{-}$ & $\stackrel{+}{0}$ & 0 & กั & 0 & 0 & $\overrightarrow{0}$ & $\overrightarrow{0}$ \\
\hline & 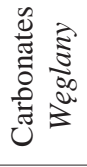 & 0 & 0 & $\exists$ & ?? & 0 & $\overrightarrow{0}$ & $\overrightarrow{0}$ & $\tilde{o}$ & 0 & 0 \\
\hline & 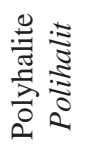 & 0 & 0 & $n$ & 0 & 0 & 0 & 0 & 0 & 0 & 0 \\
\hline & 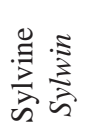 & 0 & 0 & $\underset{\text { ते }}{\ddot{\lambda}}$ & $\vec{m}$ & 0 & $\stackrel{?}{=}$ & $\stackrel{\infty}{\circ}$ & 0 & 0 & 0 \\
\hline & 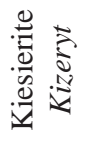 & 0 & 0 & $\begin{array}{l}b \\
\stackrel{\oplus}{-}\end{array}$ & ò & 0 & $\vec{\infty}$ & $\stackrel{+}{0}$ & 0 & $\tilde{0}$ & 0 \\
\hline & 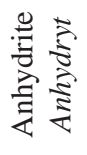 & $\stackrel{\text { Iִ }}{-}$ & $\tilde{n}$ & - & $?$ & $\tilde{c}$ & $\tilde{o}$ & $\stackrel{\infty}{0}$ & $\tilde{a}$ & $\stackrel{+}{-}$ & $\begin{array}{l}o \\
\stackrel{i}{ }\end{array}$ \\
\hline & : & $\begin{array}{l}\infty \\
\infty \\
\infty\end{array}$ & $\stackrel{n}{\infty}$ & $\begin{array}{l}\infty \\
\infty \\
i\end{array}$ & $\begin{array}{l}\infty \\
\dot{m}\end{array}$ & $\frac{n}{a}$ & $\overrightarrow{\dot{n}}$ & $\frac{a}{a}$ & ळे & 囟 & $\stackrel{m}{a}$ \\
\hline & 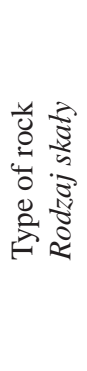 & 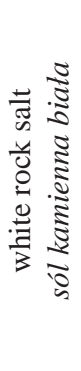 & 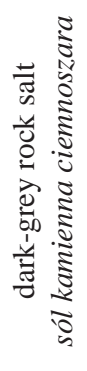 & 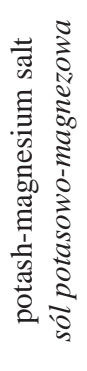 & 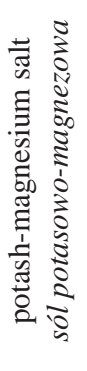 & 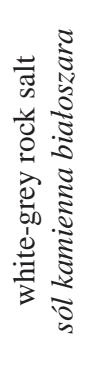 & 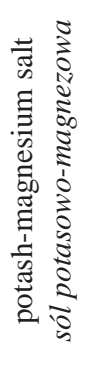 & 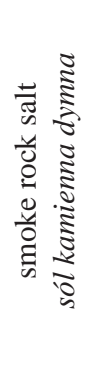 & 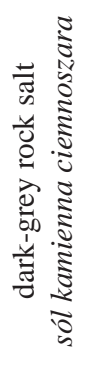 & 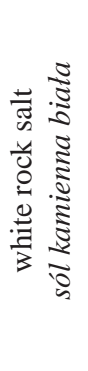 & 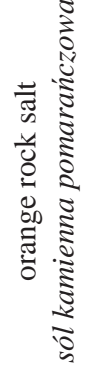 \\
\hline & 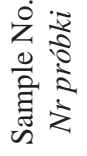 & 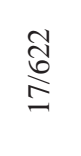 & $\begin{array}{l}\overparen{2} \\
\stackrel{0}{\Sigma}\end{array}$ & $\frac{\stackrel{2}{ }}{\underline{2}}$ & $\stackrel{ }{\stackrel{ }{\Sigma}}$ & $\stackrel{\substack{n\\
}}{=}$ & 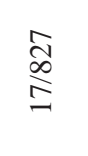 & $\underset{⿱}{\stackrel{\infty}{\Sigma}}$ & 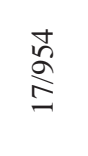 & 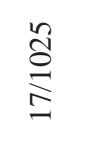 & $\underset{\Xi}{\Xi}$ \\
\hline
\end{tabular}


Lithostratigraphy of Zechstein evaporites of the central and north-werstern parts...

\begin{tabular}{|c|c|c|c|c|c|c|c|c|c|c|}
\hline 0 & 0 & 0 & $\hat{i}$ & $\underset{\sim}{\infty}$ & 0 & 0 & 0 & 0 & 0 & 0 \\
\hline$\stackrel{+}{-}$ & 0 & 0 & $\stackrel{n}{r}$ & $\vec{a}$ & 0 & 0 & 0 & 0 & 0 & 0 \\
\hline$\stackrel{\text { Iִ }}{ }$ & 0 & 0 & 0 & ?ֶ. & 0 & 0 & 0 & 0 & 0 & 0 \\
\hline ఫ্. & 0 & 0 & 0 & 0 & 0 & 0 & 0 & 0 & $\stackrel{m}{\stackrel{M}{J}}$ & 0 \\
\hline$\vec{i}$ & $\stackrel{\sim}{\mathrm{N}}$ & $\stackrel{\infty}{\circ}$ & 0 & 0 & 0 & 0 & 0 & 0 & $\stackrel{\infty}{i}$ & 0 \\
\hline$\stackrel{+}{i}$ & $\underset{0}{0}$ & $\stackrel{m}{i}$ & $\stackrel{?}{\infty}$ & $\stackrel{\substack{\infty \\
0}}{0}$ & $\sim$ & $\stackrel{\vartheta}{\dot{\gamma}}$ & $\stackrel{\circ}{\circ}$ & $\stackrel{b}{i}$ & $\stackrel{\text { Iִ }}{-}$ & $\stackrel{n}{n}$ \\
\hline$\stackrel{n}{\infty}$ & $\frac{\Upsilon}{\sigma}$ & ஜ̊ & $\hat{a}$ & $\stackrel{\circ}{\dot{m}}$ & $\stackrel{\circ}{\circ}$ & $\vec{a}$ & $\begin{array}{l}+ \\
\infty \\
\infty\end{array}$ & 囱 & $\stackrel{r}{ }$ & $\begin{array}{l}n \\
\infty \\
\infty\end{array}$ \\
\hline 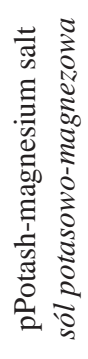 & 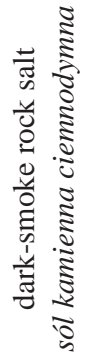 & 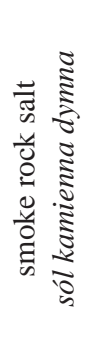 & 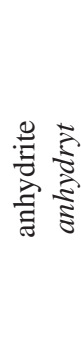 & 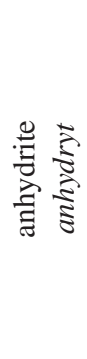 & 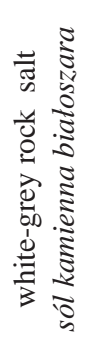 & 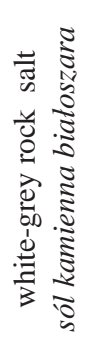 & 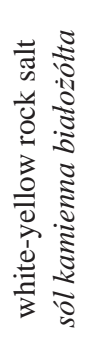 & 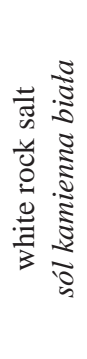 & 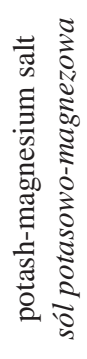 & 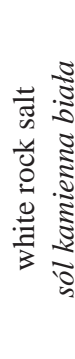 \\
\hline 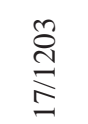 & 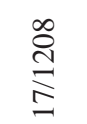 & 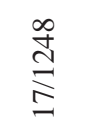 & $\begin{array}{l}\mathfrak{Z} \\
\stackrel{\mathbb{N}}{I}\end{array}$ & 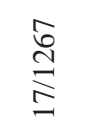 & 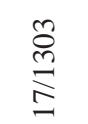 & $\underset{⿱}{\stackrel{8}{\&}}$ & $\frac{n}{\stackrel{n}{n}}$ & $\underset{\substack{8 \\
ٍ}}{\stackrel{2}{2}}$ & 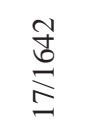 & $\frac{\mathfrak{o}}{\stackrel{6}{E}}$ \\
\hline
\end{tabular}




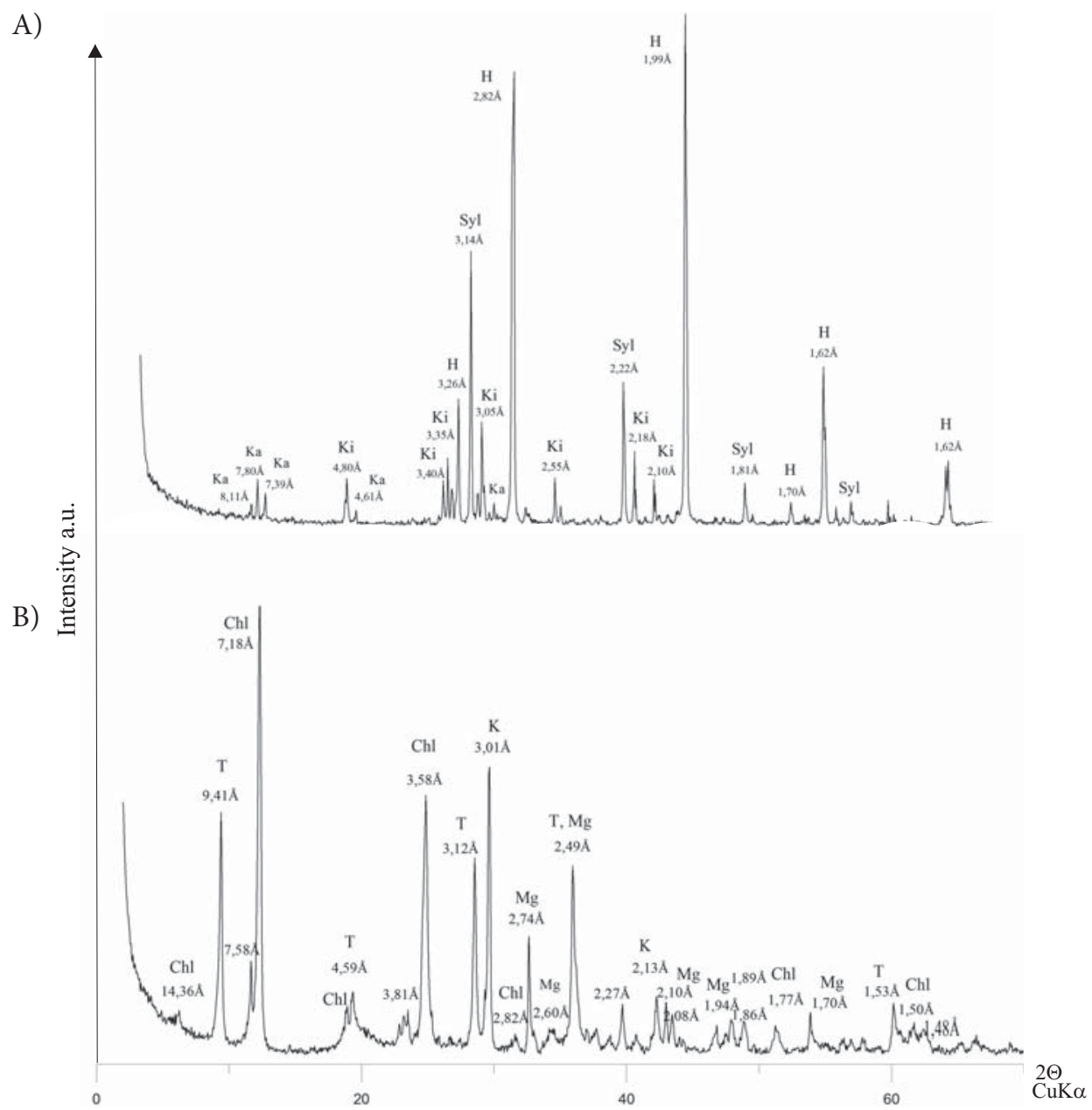

Fig. 6. A) X-Ray diffraction patterns of Kieseritic-Sylvinite. Mogilno Salt Diapir, Sample No. 9/1116, natural (raw) sample: H - Halite, Syl - Sylvine, Ki - Kieserite, Ka - Kainite. B) X-Ray diffraction patterns of hot water insoluble residue, extracted from Kieseritic-Sylvinite. Fraction $<0.1 \mathrm{~mm}$. Mogilno

Salt Diapir, Sample No. 9/1116. Chl - Chlorite, T - Talk, Mg - Magnesite, K - Calcite

Fig 6. A) Dyfraktogram rentgenowski sylwinitu kizerytowego. Wysad solny Mogilno, próbka nr 9/1116, naturalna (surowa): H - halit, Syl - sylwin, Ki - kizeryt, Ka - kainit. B) Dyfraktogram rentgenowski nierozpuszczalnego $\mathrm{w}$ gorącej wodzie residuum wydzielonego $\mathrm{z}$ sylwinitu kizerytowego, próbka nr 9/1116, frakcja < 0,1 mm. Wysad solny Mogilno. Chl - chloryt, T - talk, Mg - magnezyt, $\mathrm{K}$ - kalcyt

Microscopic studies confirmed the presence of halite, as well as trails and single plates of red hematite. No presence of kieserite was found in a thin plate. The same about sylvine or carnallite, owing to the previously mentioned strong leaching out of salt rocks. We should assume, however, that those minerals (or one of them) were the components of the studied potash salt. 
The insoluble part contents of kieserite-free potash salt amounted to ca. $4.4 \%$. Granulometric analysis indicated a large proportion of coarse fractions $(>0.6 \mathrm{~mm}=74.8 \%$ by weight) (Tab. 1). Monocrystalline anhydrite was the main component of insoluble parts. It constituted more than $99 \%$ of residual mass. Anhydrite crystals had the sizes from $0.1 \mathrm{~mm}$ to $1.5 \mathrm{~cm}$. They were the largest anhydrite crystals in that profile. Anhydrite created euhedral and subhedral crystals shaped like slats, cubes, or poles. They were mostly transparent or slightly matt, from colourless to creamy-yellow. Some of the crystals (60\%) indicated clear traces of etching on their walls. Accessory quantities of euhedral quartz crystals of up to $1.2 \mathrm{~mm}$ and euhedrally shaped boracite crystals, in the form of tetrahedral and octahedral pyrite crystals, were found. Pyrite and boracite grains did not exceed the diameter of $0.25 \mathrm{~mm}$.

Stratigraphic identification of potash-magnesium salt layers and laminas, occurring in the area of boreholes Z-9 and Z-17, was hard to establish owing to their small thickness, lack of characteristic lithostratigraphic sequences and changing sedimentation contacts with the adjacent units. What was exceptional were the sylvine-kieserite layers drilled in borehole $\mathrm{Z}-9$, at the depth of ca. 1,116 m, where their contact with zuber in the ceiling and smooth switch to dark pink salt at the bottom suggested the identification with cyclothem PZ-3 and the layer of potash-magnesium salt drilled in borehole Z-17, at the depths of $1,175 \mathrm{~m}$ and 1,203 m, whose location among smoky salts, close to main anhydrite, also suggested the identification with cyclothem PZ-3. Some of the potash salt occurrences, e.g. kieseritic sylvinite layers from borehole Z-17, at the depths of $709 \mathrm{~m}$ and $827 \mathrm{~m}$, occurred among older rock salts, and they should be assigned to cyclothem PZ-2, although with some reservation.

The presence of kieseritic sylvinite, rock salt debris and carbonate-gypsum clasts in some rocks (Fig. 5F) could indicate the epigenetic nature of those formations, recrystallizing with the circulating solutions in the cracks of tectonic dislocations that also integrated the fragments of crushed primary rocks. The secondary origin of sylvines is also supported by the fact of co-occurrence of a wide range of such accessory minerals as talk, chlorite, pyrite, quartz, boracite, magnesite, or calcite, mostly formed as euhedral crystals, which most certainly were not created in parallel with brine evaporites in a sedimentation basin. They developed rather as a result of post-sedimentation diagenetic and metamorphous processes.

Therefore, the position of kieseritic sylvinite layers and laminas found in the cores could be either primary, syn-sedimentational or epigenetic, or post-sedimentational, not connected agewise with the surrounding rocks.

\section{Zubers and clay salts}

Zuber and clay salts created two shoals, several dozens of centimetres thick, among chloride rocks of borehole Z-9, at the depths of $863 \mathrm{~m}$ and 1,113 m (Fig. 3).

Zuber from the depth of $\mathbf{8 6 3} \mathbf{~ m}$ (sample 9/863) had a sharp tectonic border at the bottom, with a torn apart anhydrite layer (sample 9/864), although the ceiling showed clearly visible smooth sedimentational switch to a higher laid pink and dark pink salt (sample 9/862). The rock displayed the features of brown zuber or grey-brown clay-salt breccia. Evaporiteterygenic components were not mixed evenly. Halite was white-greyish and pink-greyish, 
with grey clay substance; it occurred in a dispersed form between halite blasts and created clay-salt concentrations about a dozen of millimetres thick (Fig. 7A, B). The rock contained single blasts of red halite, with the diameter of 2-10 $\mathrm{mm}$. Insoluble part content amounted to $14.7 \%$. Granulometric distribution of the residue was uneven, with a small domination of a coarse fraction in which clay-sand aggregates with the diameter of up to $2 \mathrm{~cm}$ (Tab. 1) were the main components. In smaller fractions of $<0.6 \mathrm{~mm}$, in addition to the dominating polymineral sulphate-carbonate-clay debris, binocular magnifier revealed the presence of monocrystal anhydrite, magnesite, quartz, pyrite, and calcite. Chlorite and illite were identified in the clay fraction under an X-ray study. Anhydrite, constituting $15-20 \%$ of the residue mass, created subhedrally developed crystals, in the form of poles and slats, mostly $0.1-0.6 \mathrm{~mm}$ in size. Magnesite occurred in the proportion of 1-2\%, also in the form of subhedrally shaped crystals, in the size of $0.05-0.5 \mathrm{~mm}$ and with yellow-brownish colour. Quartz constituted up to $2 \%$ of insoluble residue. Allogenic and authigenic forms of that mineral were identified. Authigenic, euhedrally shaped quartz crystals, in the form of a hexagonal pole ended with bipyramids, were poorly transparent, white or grey-yellowish, with the dimensions of 0.05-0.6 $\mathrm{mm}$. Allogenic quartz, with the grain diameter of less than $0.05 \mathrm{~mm}$, occurred in a dispersed form in the salt-clay mass, often on the edges of clay and halite blast aggregates, as well as a component of clay-quartz clasts in which quartz aggregates reminded rather fragments of quatzites than sand rocks, in respect of their structures (shape and grain packing).

Zuber from the depth of $\mathbf{1 , 1 1 3} \mathbf{~ m}$ (sample 9/1113) was found in the same lithostratigraphic sequence, as that at the depth of $863 \mathrm{~m}$. At the bottom, zuber was adjacent tectonically, in a discontinuous manner, to an anhydrite layer, while in the ceiling, it smoothly changed into orange-pink salt, with clay salt layers. It was composed of white-greyish, orange and light brownish salt and grey and red-brownish clay. Halite blasts had the dimensions from $1 \mathrm{~mm}$ to $30 \mathrm{~mm}$, and they were often red-brownish in colour. Crystals with a chevron structure and several centimetre large fibrous halite inserts were found. Clay substance was dispersed between halite blasts and it created concentrations with the diameter from $1 \mathrm{~mm}$ to $15 \mathrm{~mm}$. X-ray analysis of grey and red-brownish clay concentrations indicated that they were composed of similar minerals: chlorite, illite, quartz, anhydrite, and halite (Fig. 8).

Fig. 7. A) Halite blasts surrounded by silt-carbonate substance in zuber, Pol. 1. B) Halite blasts surrounded by silt-carbonate substance in zuber, Pol. X. C) Directionally laid anhydrite blasts with carbonate laminas, Pol. X. D) Euhedral anhydrite crystal in halite, Pol. X. E) Anhydrite blasts, with carbonate-clay lamina in anhydrite, Pol. 1. F) Parallel elongated blasts/crystals at the contact area of anhydrite and rock salt, Pol. X. A - Anhydrite, H - Halite, C - Carbonates, CQC - Aggregates: clay minerals-quartz-carbonates.

(Note: Thin scratches on crystal surfaces are artefacts of sample grinding)

Fig. 7. A) Blasty halitu otoczone substancją ilasto-węglanową w zubrze, Pol. 1. B) Blasty halitu otoczone substancją ilasto-węglanową w zubrze, Pol. X. C) Kierunkowo ułożone blasty anhydrytu z laminami węglanowymi, Pol. X. D) Euhedralny kryształ anhydrytu w halicie, Pol. X. E) Blasty anhydrytu z laminą węglanowo-ilastą w skale anhydrytowej, Pol. 1. F) Równolegle ułożone, wydłużone blasty/kryształy anhydrytu na kontakcie anhydrytu i soli kamiennej, Pol. X. A - anhydryt, H - halit, $\mathrm{C}$ - węglany, CQC - agregaty ilasto-kwarcowo-węglanowe.

(Uwaga: Cienkie rysy na powierzchniach kryształów to artefakty po szlifowaniu próbki) 
Insoluble part content was $13.2 \%$. Granulometric distribution of residue was similar to that of zuber from the depth of $863 \mathrm{~m}$ (Tab. 1). Sulphate-carbonate-clay rock debris dominated. We should point out that the sample contained a very large quantity of euhedral, authigenic quartz crystals: up to $30 \%$, which clearly distinguished the sample from zuber sample $9 / 863$.
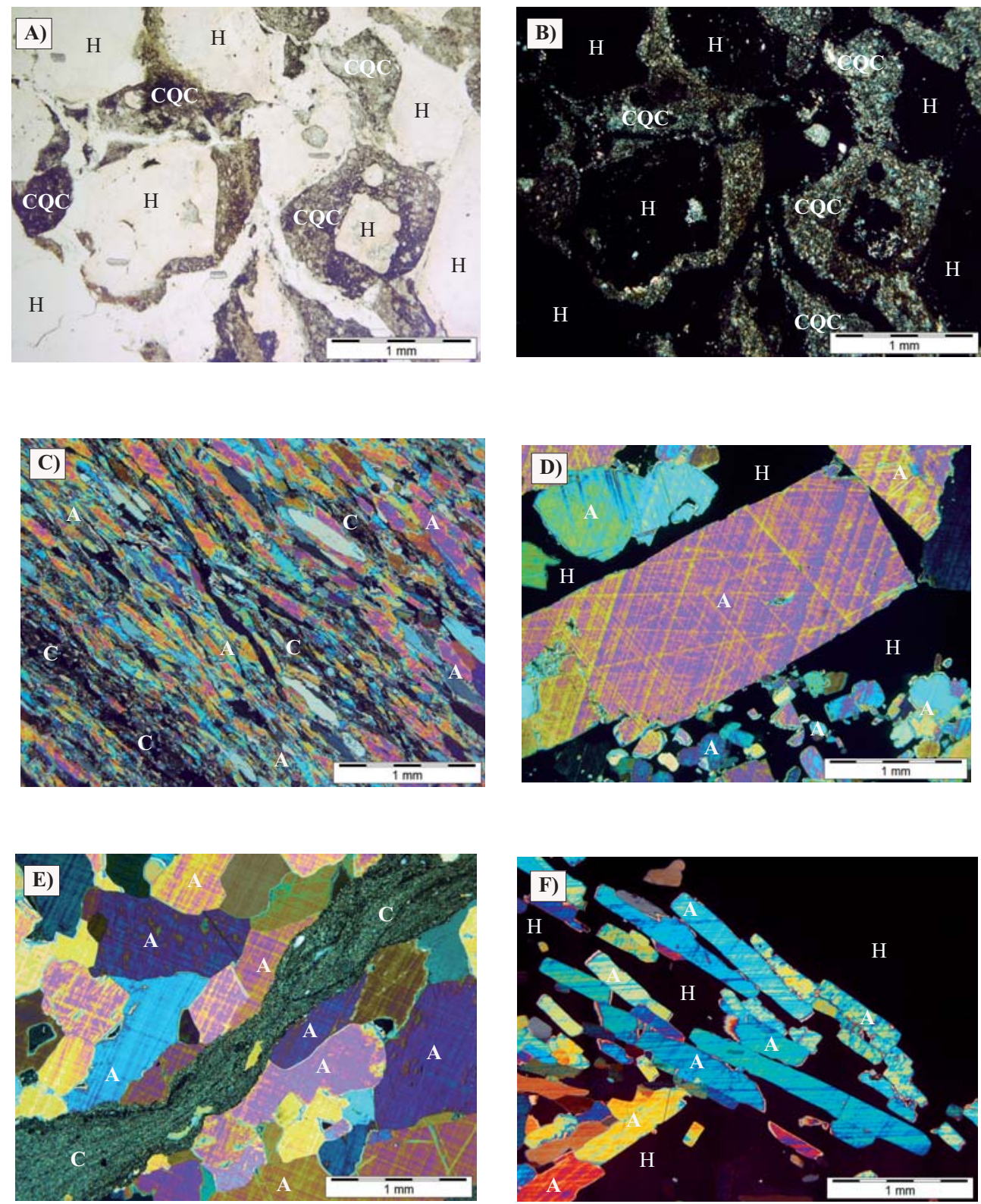


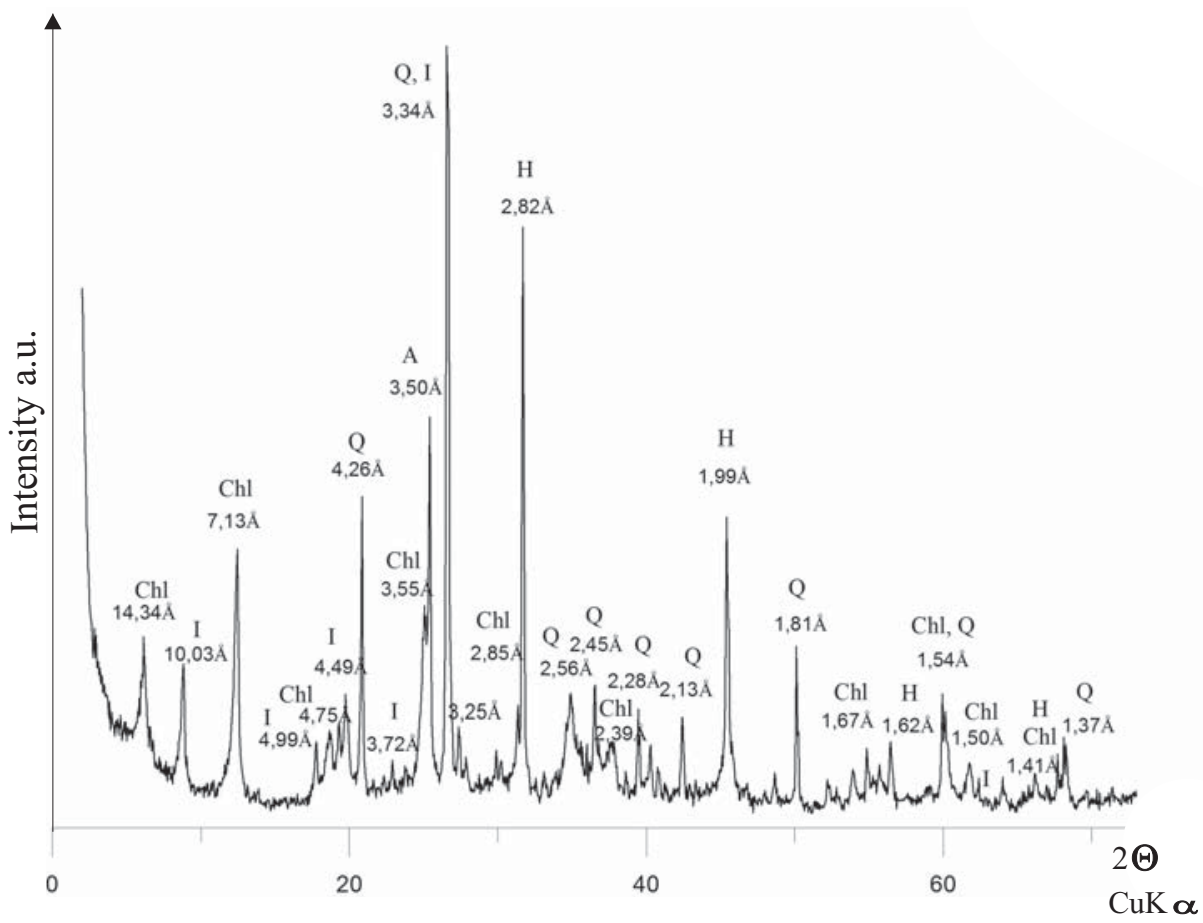

Fig. 8. X-Ray diffraction patterns of clay-salt substance, extracted from grey-brown zuber. Mogilno Salt Diapir, Sample No. 9/1116: A - Anhydrite, Chl - Chlorite, H - Halite, I - Illite, Mg - Magnesite, Q - Quartz

Fig. 8. Dyfraktogram rentgenowski substancji ilasto-solnej, pobranej z zubra szarobrunatnego. Wysad solny Mogilno. Próbka 9/1113: A - anhydryt, Chl - chloryt, H - halit, I - illit, Mg - magnezyt, Q - kwarc

In that zuber layer, quartz created transparent crystals and their complexes, with red-orange colour. Monocrystalline anhydrite occurred in the quantity of up to $10 \%$, creating subhedral crystals, in the form of poles and slats. Magnesite occurred in the form of subhedrally and euhedrally shaped crystals, with the dimensions of $0.1-0.6 \mathrm{~mm}$ and honey-yellowish colour. Its contents did not exceed $3 \%$ of the residue volume.

The mineralogical and petrographic analysis indicated clearly that, despite small quantitative differences found in the mineral composition, both zuber formations, occurring at the depths $863 \mathrm{~m}$ and $1,113 \mathrm{~m}$, belonged to the same lithostratigraphic unit which was doubled in the profile. The layer sequence (zuber and neighbouring layers at the bottom and in the ceiling) was repeated in the profile twice in the same order: $1-2-3 \leftrightarrow 1-2-3$. That indicated that the repetition was not a result of drilling through the wings of the same straight fold, where the sequence would have to be: $1-2-3 \leftrightarrow 3-2-1$, but rather the repetition was the effect of more complex deposit tectonics. The vicinity of potash and grey-pinkish salts, anhydrites, and potash salt inclusions in zubers clearly indicated the identification of that formation with cyclothem PZ-3. 


\section{Anhydrites}

Anhydrites occurring in the areas of boreholes Z-9 and Z-17 did not create continuous deposits or layers complying with the adjacent formations in terms of sedimentation and stratigraphic compliance. The contact with the surrounding rocks was mostly tectonic.

In borehole Z-9, anhydrites created 3 layers, with the thickness of 15-30 cm (Fig. 3). The first two of them were located at the depths $864 \mathrm{~m}$ and 1,114 m, between zubers and orange-pinkish clayed salts. The third layer of the depth of 1,530 m located in the ceiling had a tectonic contact with white rock salt of the bottom and it bordered orange salt. The anhydrite layers were composed of rock fragments of the size from several to about a dozen of centimetres, bound by rock salt. Numerous pits after leached potash-magnesium salts are visible in places of contact with pink salt.

Anhydrite rocks of all three cyclothems indicated a considerable similarity. They were light grey, with usually granoblastic structure. Some anhydrite fragments contained strongly elongated blasts creating lepidoblastic structure, being a clear symptom of crystallization in tectonic stress conditions (under pressure) (Fig. 7C). The dimensions of anhydrite blasts were changing, from $0.05 \mathrm{~mm}$ to several millimetres. At the contact area of anhydrite and rock salt, there was obviously more intensely recrystallized anhydrite, which, owing to a larger blastic force from halite, created several millimetre large euhedral crystals among halite blasts (Fig. 7D). The texture of the rocks was either unordered or layered in parallel, emphasized by a parallel system of elongated anhydrite blasts, separated by carbonate micrite laminas and lenses (Fig. 7C).

Large mineralogical and petrographic similarity of anhydrites (and of the sequence of surrounding rocks) located at the depths of $864 \mathrm{~m}$ and 1,114 m (Fig. 3) indicated that they belonged to the same layer, which was drilled through twice. The identity of the layer of $1,530 \mathrm{~m}$ with those mentioned above was also very probable, although difficult to ascertain owing to the core interruption and lack of data about the rocks below.

The comparative studies and analyses indicated that the anhydrite layer of the area of borehole Z-9, laid among orange clay salts and zubers, in the vicinity of potash-magnesium salts, occupied the stratigraphic position which was typical for anhydrite layers A, B, and C of the middle part of cyclothem PZ-3. We can assume with good probability that it was a torn apart layer of one of those anhydrites.

Borehole Z-17 was drilled through anhydrite rock laid among white rock salts of cyclothem PZ-2, at the depth of 1,255-1,267 m. Sharp contact with the surrounding salts and non-compliant shoals indicated that it was a fragment of a layer, not a complete deposit.

The rock was white-greyish in colour, locally changing to dark grey, with dense lamination (every 1-3 $\mathrm{mm}$ ) by dark trails of carbonate-clay substances, which emphasized a parallel layered rock texture (Fig. 7E). X-ray analysis indicated that dark laminas were composed of anhydrite and magnesite, with small admixtures of chlorite and quartz (Fig. 9). The structure of the rock was diverse: at the contact areas with anhydrite and rock salt, anhydrite, showing 
a larger blastic force, built between halite blasts euhedrally formed blasts, in the form of elongated poles and slats, several to about a dozen millimetres long, laid in parallel to the contact area with salt, created the directional- flat- parallel texture (Fig. 7F). Inside the rock, in the zone of limited freedom of recrystallization, anhydrite grains with similar blastesis power formed a granoblastic structure composed of anhedral blasts (Fig. 7E). Flat-paralleldirectional texture of the anhydrite rock was a clear symptom of recrystallization under pressure, resulting from halotectonic processes.

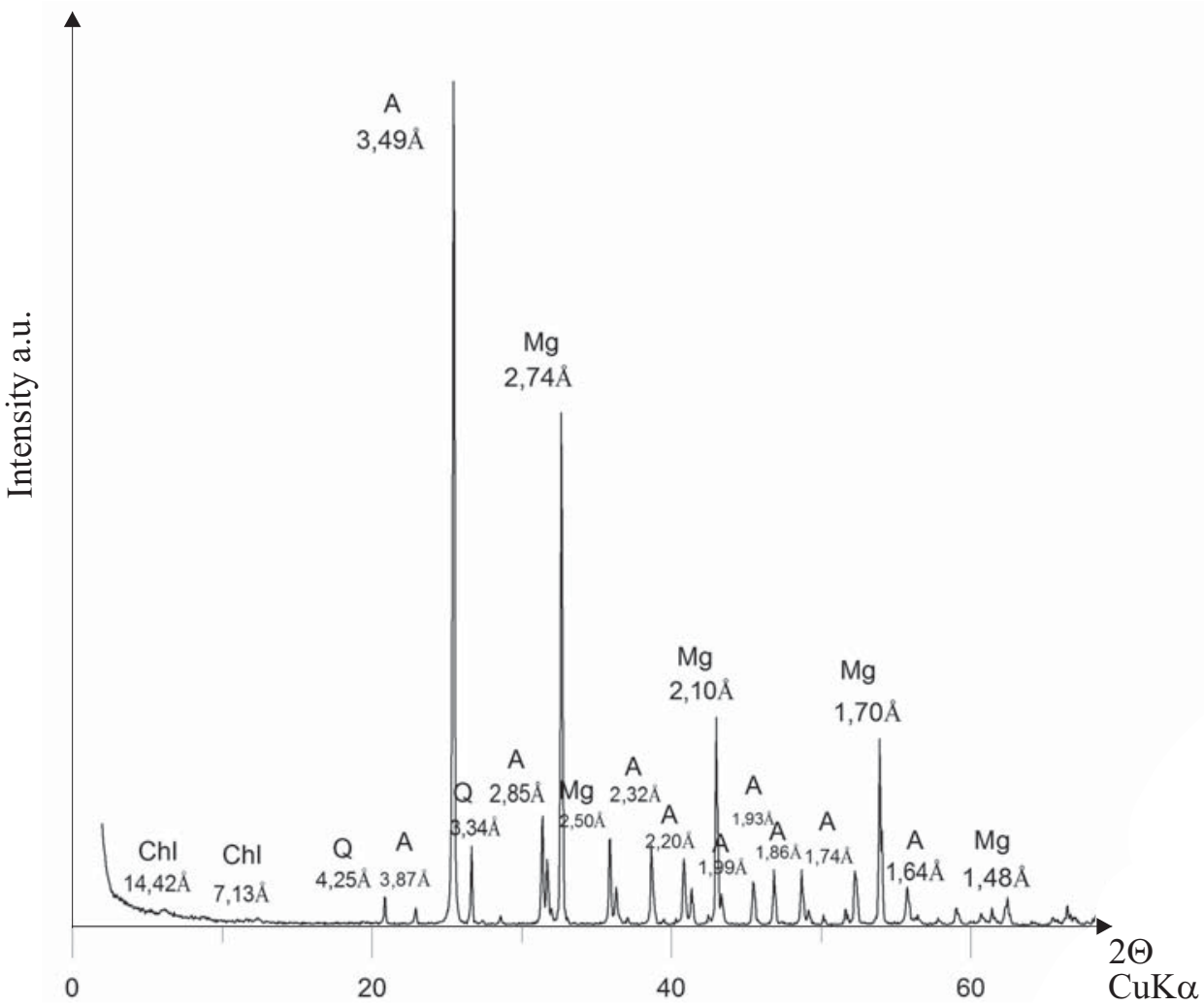

Fig. 9. X-Ray diffraction patterns of carbonate-clay substance, extracted from dark-grey lamina in Anhydrite. Main Anhydrite (A-3), Sample No. 17/1267, Mogilno Salt Diapir: A - Anhydrite, Chl - Chlorite, Mg - Magnesite, Q - Quartz

Fig. 9. Dyfraktogram rentgenowski substancji węglanowo-ilastej pobranej z ciemnoszarej laminy występującej w anhydrycie. Anhydryt główny (A-3), próbka 17/1267: Chl - chloryt, Q - kwarc, A - anhydryt, $\mathrm{Mg}$ - magnezyt

Close to the anhydrite block boundaries, there appeared epigenetic fibrous halite veins and several centimetre long, epigenetic crystal halite nests, with milky-greenish fine-crystalline polyhalite. 
Polyhalite was attached closely to anhydrite, but it had a bay-like boundary with halite. Polyhalite-halite incrustations were identified on the basis of X-ray diffraction analysis (Fig. 10).

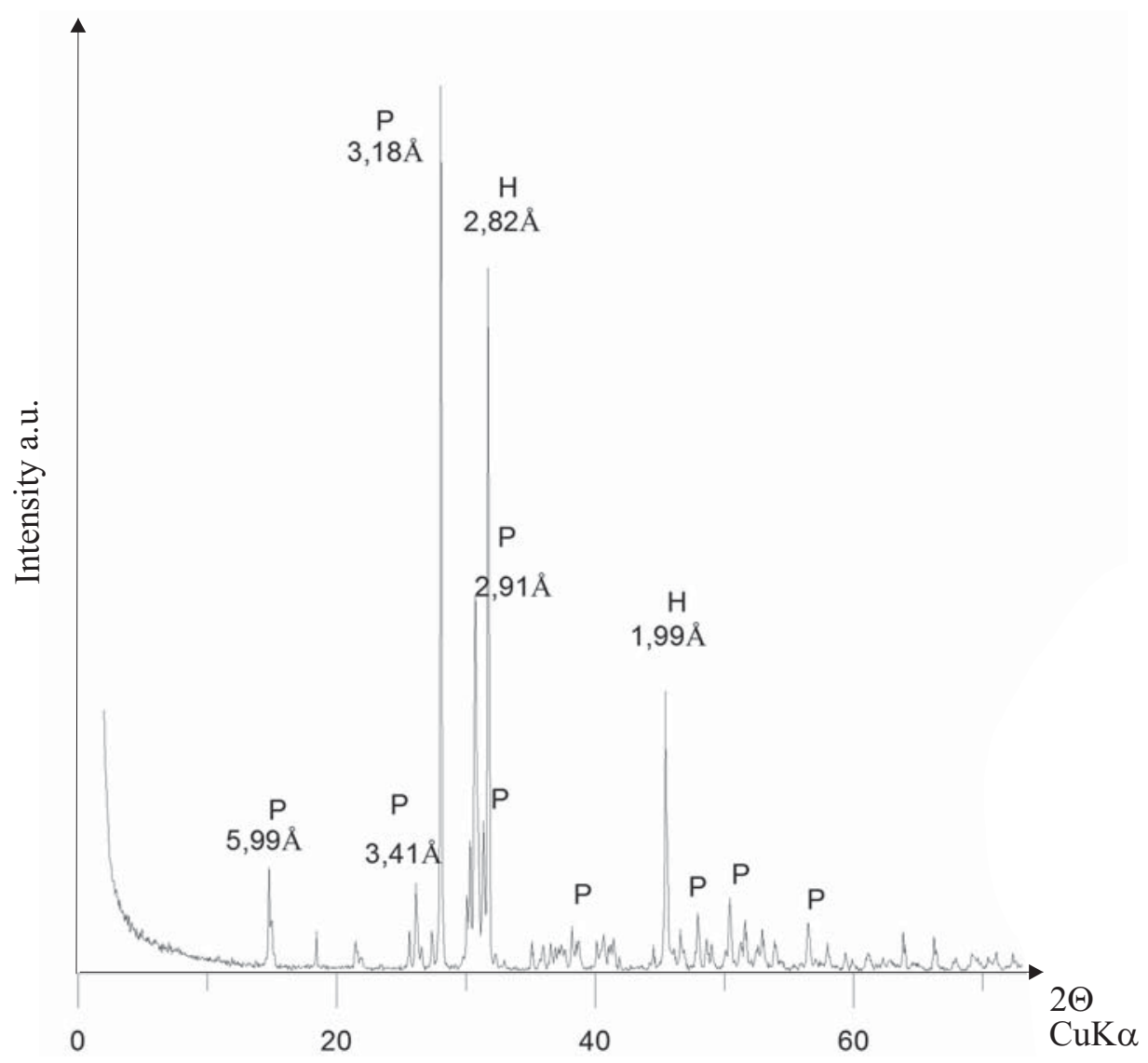

Fig. 10. X-Ray diffraction patterns of white-green polyhalite-halite concentration extracted from anhydrite. Main Anhydrite (A-3), Sample No. 17/1267: P - Polyhalite, H - Halite

Fig. 10. Dyfraktogram rentgenowski białozielonych kryształów polihalitu i halitu, tworzących epigenetyczne ,gniazda” w anhydrycie. Anhydryt główny (A-3), próbka 17/1267: P - polihalit, H - halit

Anhydrite originating from the area of borehole Z-17 had typical petrographic and mineralogical features of main anhydrite. The method of deposition, the contact with the surrounding rocks, and the block dimensions indicated that it was a fragment of a Main Anhydrite deposit (A-3) from the bottom of cyclothem PZ-3, torn apart and elevated into the upper sections of the diapir by the older salt ( $\mathrm{Na} 2)$ anticlines intruding towards the surface. 


\section{ANALYSIS \\ OF WATER-INSOLUBLE (HARDLY WATER SOLUBLE) PART CONTENTS SEPARATED FROM THE ROCKS OF BOREHOLES Z-9 AND Z-17}

The water-insoluble (hardly water soluble) mineral contents of the rocks obtained from boreholes Z-9 and Z-17 ranged from $0.14 \%$ to $14.7 \%$ by weight. The largest proportion of water-insoluble residue was found in zubers (samples 9/863 and 9/1113) and the rock salts with large admixtures of anhydrite (samples 9/1530, 17/663, and 17/954). The smallest proportions of insoluble parts were observed in potash salts, with a large proportion of kieserite, determined to be kieseritic sylvinite. That was associated with a very small quantity of anhydrite in those salts (sample 9/1116-0.2\%, sample 17/827 -0.14\%). However, the insoluble part contents were oscillating around 1-3\% in the majority of rock salts. Anhydrite is the dominating mineral of hardly water-soluble residue. Its contents amounted to $98-100 \%$ in the majority of samples. In addition, the presence of such minerals as quartz, magnesite, dolomite, calcite, boracite, pyrite, talk, chlorite, illite, hematite, and gypsum was determined (Gypsum, found in zubers in the form of idiomorphous crystals, is most probably a presentday epigenetic mineral). They occurred in accessory quantities, and their proportions ranged from tenths of a percent to $2 \%$.

The granulation of insoluble parts, separated from salt rocks of boreholes Z-9 and Z-17 indicated considerable changeability, from clay fraction of several microns (in clay salts and zubers) to several centimetre large in zubers and some chloride rocks. In coarse fractions of $>2 \mathrm{~mm}$, mainly microcrystalline debris of anhydrite and carbonate-clay-sand rocks were located (in zubers). In samples 17/1203 and 17/1237, collected from potash salt layers, a considerable presence of large monocrystal anhydrites of up to $1.5 \mathrm{~cm}$ were found. In medium fractions, from $2 \mathrm{~mm}$ to $0.1 \mathrm{~mm}$, mainly forms of monocrystalline anhydrite and some accessory minerals (authigenic quartz, carbonates, boracite, and pyrite) were located. The finest fractions of less than $0.1 \mathrm{~mm}$ were created by anhydrite, allogenic quartz, carbonates, and clay minerals which shifted to pelite fraction. A large majority of waterinsoluble material was concentrated in the fractions of $0.6-0.1 \mathrm{~mm}$, with usually more than $80 \%$ share.

In the granulometric distribution of residue, regularity was observed, consistently repeating in all analysed rock salt samples. In the rock salts of cyclothem PZ-2, a large majority of insoluble parts were located in the range of $0.25-2.0 \mathrm{~mm}$, while in case of the rock salts of cyclothem PZ-3, insoluble parts had smaller dimensions and they were located in the fractions of $<0.25 \mathrm{~mm}$ (Tab. 1, 2, Fig. 11). That difference was associated mainly with the anhydrite grain sizes. That regularity was also observed in the Kłodawa diapir evaporites.

A clear difference found in the granulometric distribution of water-insoluble residue of the rock salts of cyclothems PZ-2 and PZ-3 was one of valuable diagnostic petrographic features allowing us to distinguish those sediments. 

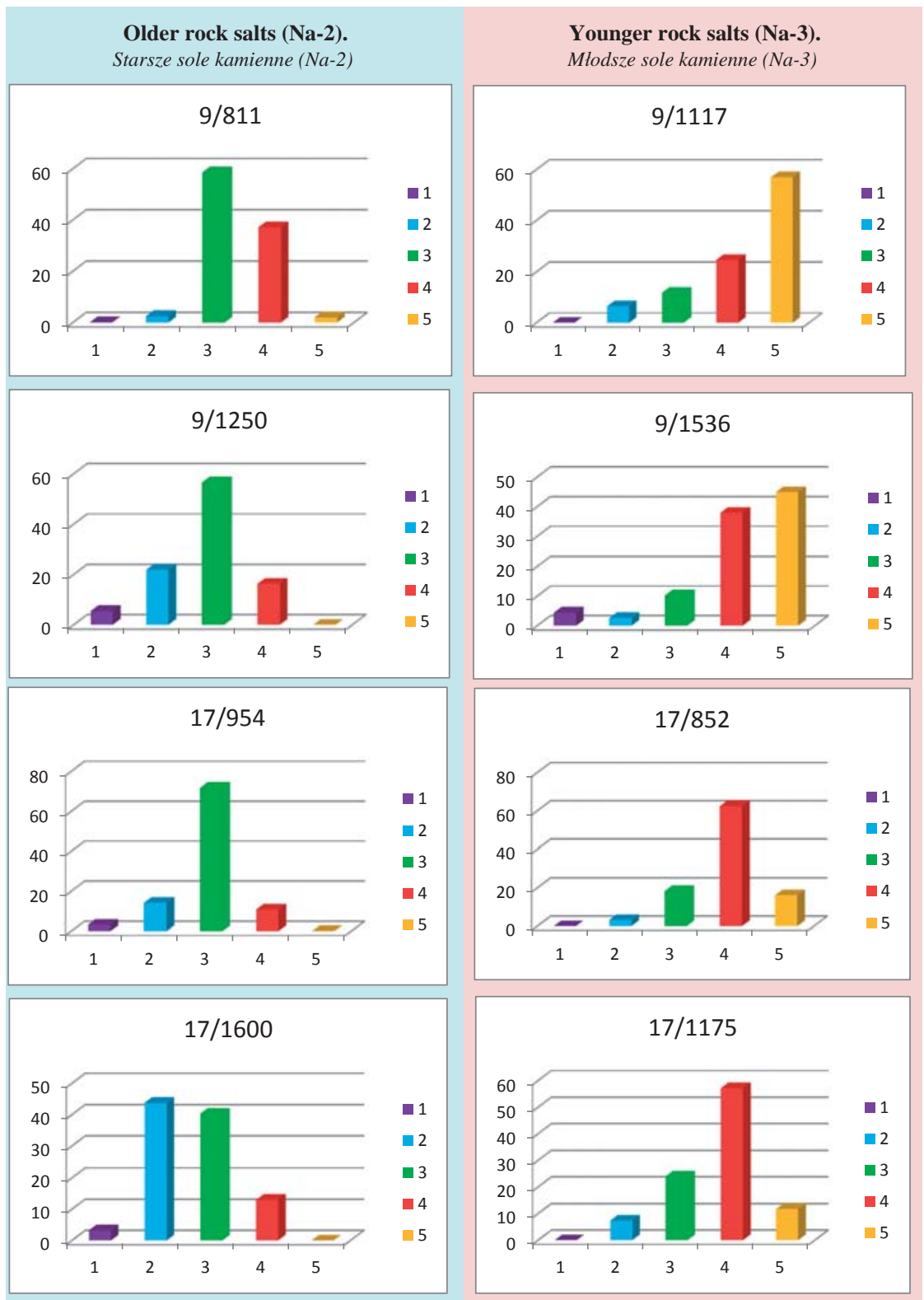

Fig. 11. Typical grain distribution of insoluble residue from older rock salts $(\mathrm{Na}-2)$ and younger rock salts (Na-3): 1 - grain size $>2 \mathrm{~mm} ; 2-2-0.6 \mathrm{~mm} ; 3-0.6-0.25 \mathrm{~mm} ; 4-0.25-0.1 \mathrm{~mm} ; 5-<0.1 \mathrm{~mm}$

Fig. 11. Typowe rozkłady granulometryczne części nierozpuszczalnych w starszych solach kamiennych (Na-2) i młodszych solach kamiennych (Na-3). Wielkość ziaren: 1 - >2 mm; 2 - 2-0,6 mm; $3-0,6-0,25 \mathrm{~mm} ; 4-0,25-0,1 \mathrm{~mm} ; 5-<0,1 \mathrm{~mm}$ 


\section{MICROSCOPIC MEASUREMENTS OF SALT ROCK FISSURES ${ }^{1}$}

Microscopic studies (Tabs 5,6) indicated that rock salt fissures at the place of drilling boreholes Z-9 and Z-17 in the diapir was insignificant.

\section{Table (Tabela) 5}

Measurement of fissility of rock salt from borehole Z-17

Pomiary szczelinowatości skat solnych w otworze Z-17

\begin{tabular}{|c|c|c|}
\hline $\begin{array}{l}\text { Sample No. } \\
\text { Nr próbki }\end{array}$ & $\begin{array}{l}\text { Type of rock } \\
\text { Rodzaj skaty }\end{array}$ & $\begin{array}{c}\text { Width of joint }[\mu \mathrm{m}] \\
\text { Szerokość szczelin }[\mu \mathrm{m}]\end{array}$ \\
\hline $17 / 709$ & $\begin{array}{l}\text { potash-magnesium salt } \\
\text { sól potasowo-magnezowa }\end{array}$ & $<1.0$ \\
\hline $17 / 710$ & $\begin{array}{l}\text { potash-magnesium salt } \\
\text { sól potasowo-magnezowa }\end{array}$ & $<1.0$ \\
\hline $17 / 818$ & white rock salt, sól kamienna biała & $<1.0$ \\
\hline $17 / 827$ & $\begin{array}{l}\text { potash-magnesium salt } \\
\text { sól potasowo-magnezowa }\end{array}$ & $<1.0$ \\
\hline $17 / 852$ & smoke rock salt, sól kamienna dymna & $<1.0$ \\
\hline $17 / 954$ & $\begin{array}{l}\text { dark-grey rock salt } \\
\text { sól kamienna szara }\end{array}$ & $<1.0$ \\
\hline $17 / 976$ & $\begin{array}{l}\text { potash-magnesium salt } \\
\text { sól potasowo-magnezowa }\end{array}$ & 1.0 \\
\hline $17 / 1113$ & $\begin{array}{c}\text { orange rock salt } \\
\text { sól kamienna pomarańczowa }\end{array}$ & $<1.0$ \\
\hline $17 / 1208$ & $\begin{array}{l}\text { dark-smoke rock salt } \\
\text { sól kamienna ciemnodymna }\end{array}$ & 1.0 \\
\hline $17 / 1248$ & $\begin{array}{c}\text { smoke rock salt } \\
\text { sól kamienna dymna }\end{array}$ & $<1.0$ \\
\hline $17 / 1255$ & anhydrite, anhydryt & $<1.0$ \\
\hline $17 / 1265$ & anhydrite, anhydryt & 1.2 \\
\hline $17 / 1267$ & anhydrite, anhydryt & 1.3 \\
\hline $17 / 1303$ & $\begin{array}{c}\text { white-grey rock salt } \\
\text { sól kamienna białoszara }\end{array}$ & 1.0 \\
\hline $17 / 1375$ & white rock salt, sól kamienna biała & $<1.0$ \\
\hline $17 / 1475$ & $\begin{array}{l}\text { white-grey rock salt } \\
\text { sól kamienna białoszara }\end{array}$ & $<1.0$ \\
\hline $17 / 1625$ & white rock salt, sól kamienna biała & $<1.0$ \\
\hline
\end{tabular}

\footnotetext{
${ }^{1}$ Median of 50 measurements for each sample.
} 


\section{Table (Tabela) 6}

Measurement of fissility of rock salt from borehole Z-9

Pomiary szczelinowatości skat solnych w otworze Z-9

\begin{tabular}{|c|c|c|}
\hline $\begin{array}{c}\text { Sample No. } \\
\text { Nr próbki }\end{array}$ & $\begin{array}{c}\text { Type of rock } \\
\text { Rodzaj skaty }\end{array}$ & $\begin{array}{c}\text { Width of joint }[\mu \mathrm{m}] \\
\text { Szerokość szczelin }[\mu \mathrm{m}]\end{array}$ \\
\hline $9 / 882$ & $\begin{array}{c}\text { white rock salt } \\
\text { sól kamienna biata }\end{array}$ & $<1.0$ \\
\hline $9 / 862$ & $\begin{array}{c}\text { dark-orange salt } \\
\text { sól ciemnopomarańczowa }\end{array}$ & $<1.0$ \\
\hline $9 / 863$ & $\begin{array}{c}\text { brown zuber } \\
\text { zuber brunatny }\end{array}$ & $<1.0$ \\
\hline $9 / 864$ & $\begin{array}{c}\text { anhydrite } \\
\text { anhydryt }\end{array}$ & $<1.1$ \\
\hline $9 / 884$ & $\begin{array}{c}\text { white rock salt } \\
\text { sól kamienna biała }\end{array}$ & $<1.0$ \\
\hline $9 / 920$ & $\begin{array}{c}\text { white rock salt } \\
\text { sól kamienna biała }\end{array}$ & 1.2 \\
\hline $9 / 1114$ & $\begin{array}{c}\text { zuber and anhydrite } \\
\text { zuber z anhydrytem }\end{array}$ & 1.0 \\
\hline $9 / 1530$ & $\begin{array}{c}\text { anhydrite } \\
\text { anhydryt }\end{array}$ & $<$ \\
\hline
\end{tabular}

One could observe there cracks reaching up to one micron. Cracks exceeding one micrometer were found mainly in those portions of the core profile, in which large quantities of anhydrite laminas were identified or within anhydrites. In the majority of cases, fissures were closed. Consequently, the travel of hydrocarbons within rock salts was insignificant or next to none in that area of the diapir.

\section{CONCLUSIONS}

- As a result of these studies, it was found that boreholes Z-9 and Z-17 were drilled through evaporite and siliciclastic rocks of the Zechstein salt series of cyclothems PZ-2 and PZ-3 (older and younger salts). No cyclothem PZ-4 formations were recognized. We could not definitely exclude the presence of oldest rock salt (Na-1), which could be tectonically squeezed in between PZ-2 salts. However, considering the macroscopic and microscopic mineralogical and petrographic features of the studied rocks, the presence of the oldest salts seemed to be hardly probable.

- The formations in question were formed tectonically. The layers were placed at the angles from $60^{\circ}$ to $90^{\circ}$. Natural (sedimentation) sequence of layers was observed only in certain profile fragments, mainly in thick rock salt complexes. 
- The sequence of layers observed in the profiles (Figs 3,4) was astratigraphic. Many units were reduced or completely wedged. Such rigid rocks as anhydrites, shale or zuber were torn into blocks, boulders or debris and dragged out within the diapir up to its surface by elevating rock salt anticlines. We found them often in that form in the drilled cores.

- In the ceiling and bottom sections of the drilled-through rocks, the older rock salts (Na-2) were fund, while thin and reduced younger series (Na-3), separated tectonically with older salts (anticlines?), were revealed in the middle section.

- The evaporites of cyclothem PZ-2 were represented by white and white-greyish salts, with many transitional hues, and scarce thin potash salt inserts, represented by kieseritic sylvinite. The presence of small kainite and polyhalite admixtures in those salts indicated typical hard salt compositions. The mineral composition calculated with chemical data indicated that we dealt with hard sylvine-kieserite salt, with kainite admixtures.

- The cyclothem PZ-3 rocks were composed of orange-pink, both pure and clayed, and smoky rock salts (found in the Kujawy region diapirs for the first time), as well as zubers, clay salts and anhydrites, with laminas and thin layers of potash-magnesium salts (hard salt as above and potash salts without kieserite).

- A number of mineralogical and petrographic features, presented in this study, indicated the epigenetic character of potash-magnesium salts found in boreholes Z-9 and Z-17.

- In the borehole Z-9 and Z-17 cores, we did not identify any presence of such correctly deposited lead horizons as anhydrites (A-1, A-2 and A-3), dolomites (Ca-2), grey salt clay (T-3), and stinking schist (T-2), or clear mineral horizons that had been well documented in other salt diapirs, e.g. those of Kłodawa, and used as lithostratigraphic tools (Werner et al. 1960, Burliga et al. 2008, Wachowiak 2010, Czechowski et al. 2011). Clear lithostratigraphic separation of the studied layers was difficult to acquire in the conditions of tectonic development of the layers where rock salts of various ages were in direct contact with each other, without the presence of the above-mentioned lead horizons.

- In the studied evaporite and siliciclastic rocks, the occurrence of 18 minerals was identified, e.g. halite, sylvine, kieserite, epsomite, polyhalite, kainite, anhydrite, gypsum, boracite, magnesite, dolomite, calcite, quartz, talk, chlorite, illite, pyrite, hematite. We should mention that epsomite, occurring abundantly on the surface of potash-magnesium salts, is the present-day product of kieserite weathering (hydration). Gypsum, found in zubers in the form of idiomorphous crystals, is also most probably a present-day epigenetic mineral.

- Detailed characteristics of those minerals, as well as of other processes and mineralogical and geo-chemical transformations occurring in the drilled-through deposit, will be the object of a separate study.

\section{FINAL REMARKS}

Owing to intense continuation of the expansion of the underground natural-gas storage facility in the Mogilno II deposit (construction of 10 more caverns), it is absolutely necessary to recognize in detail the internal geological structure of the Mogilno diapir to determine the best possible locations for those caverns. 
That can be attained by supplementing the generally applied geo-physical methods with such classical geological studies as:

- lithostratigraphic correlation of the layers between the existing boreholes,

- detailed mineralogical and petrographic analysis of drilled-through rocks,

- rigorous cartographic interpretation (2D and 3D geological maps) based on the data obtained from studies.

The financial expenditures allocated for classical geological studies are small in comparison to the costs of technologically advanced geophysical studies and the total costs of storage cavern construction. However, geological studies provide huge quantities of additional and valuable information that reduce greatly the risk of wrong project placement.

The studies were conducted at the Faculty of Geology, Geophysics and Environment Protection of the AGH University of Science and Technology in Krakow. They were financed by Investgas SA under Agreement No. 439/KPMG/U/2011.

The authors would like to thank Investgas SA for making the core materials available. We are particularly grateful to Ms. Teresa Laskowska, President of Investgas SA, and Mr. Kazimierz Gaska, Vice-President of Investgas SA and Director of KPMG Mogilno, for their logistic and substantive assistance during our studies.

\section{REFERENCES}

Burliga S., Czechowski F. \& Hojniak M., 2008. Gas-dynamic phenomena in the Kłodawa Salt Diapir as a Zechstein stratigraphic tool. Gospodarka Surowcami Mineralnymi, 24, 69-81.

Czechowski F., Burliga S., Hojniak M., 2011. Geochemistry of hydrocarbons from the first time documented occurrence of Main Dolomite (Ca2) in the Kłodawa Salt Dome. Geologia, 37, 2, 231-244.

Dadlez R., 1997. Epicontinental bisins in Poland: Devonian to Cretaceous - relationship between the crystalline basement and sedimentary infill. Geological Quarterly, 41, 419-432.

Dadlez R. \& Marek S., 1998. Major faults, salt- and non-salt anticlines. In: Dadlez R., Marek S. \& Pokorski J. (Eds), Paleogeographic Atlas of Epicontinental Permian and Mesozoic in Poland (1:2 500 000), Państwowy Instytut Geologiczny, Warszawa.

Garlicki A. \& Szybist A., 1986. Salinarne osady polskiego cechsztynu z solami potasowo-magnezowymi (Saline deposits of Polish Zechstein with potash salt). Gospodarka Surowcami Mineralnymi, 2, 3-3, 384-404.

Krzywiec P., 2006. Structural inversion of the Pomeranian and Kujavian segments of the Mid-Polish Trough - Lateran variations i timing and structural style. Geological Quarterly, 50, 151-168.

Pawlikowski M. 2008. Skały ewaporatowe (gipsowo-solne) (Evaporites rocks (gypsum-salts)). In: Manecki A. \& Muszyński M. (red.), Przewodnik do petrografii, UWND AGH, Kraków, 375-385. 
Pawlikowski M., 2009. Ewaporaty. Nowe dane minerologiczno-petrograficzne (Evaporites. New mineralogical-petrographical data). Geologia, 35, 3, 407-425.

Sokołowski J., 1966. Rola halokinezy w rozwoju osadów mezozoicznych i kenozoicznych struktury Mogilna i synklinorium mogileńsko-łódzkiego (The role of halokinesis in the development of mesozoic and cainozoic deposits of the Mogilno structure and of the Mogilno-Łódź Synclinorium). Instytut Geologiczny, Warszawa (with English summary).

Wachowiak J., 2010. Poziomy mineralne w solach cechsztyńskich wysadu solnego Kłodawa jako narzędzie korelacji litostratygraficznej (Mineral levels in Upper Permian (Zechstein) salts of the Kłodawa salt diaper as a tool for lithostratigraphic correlation). Geologia, 36, 3, 367-393.

Wachowiak J. \& Pawlikowski M., 2011a. Szczegółowe badania mineralogiczno-petrograficzne skat ewaporatowych otworu badawczego Z-9 w złożu Mogilno II, w wysadzie solnym Mogilno. Investgas SA Archives.

Wachowiak J. \& Pawlikowski M., 2011b. Szczegółowe badania mineralogiczno-petrograficzne skat ewaporatowych otwory badawczego Z-17 w złożu Mogilno II, w wysadzie solnym Mogilno. Investgas SA Archives.

Werner Z., Poborski J., Orska J. \& Bąkowski J., 1960. Złoże solne w Kłodawie w zarysie geologiczno-graniczym (Kłodawa salt deposit in the geological and mining outline). Prace Instytutu Geologicznego, 30, 467-494.

Wilkosz P., 2001. Geological evolution and kinematics of the Mogilno salt structure in the Cenozoic. Institute of Geology, Adam Mickiewicz University, Poznań (Ph.D Thesis).

Wilkosz P., 2006. Quaternary Activities of Salt Structures in Poland - New Data from the Mogilno Salt Dome. Z. Geol. Wiss., 33, 4/5, 243-261.

\section{Streszczenie}

Wysad solny Mogilno jest jedną z kilkudziesięciu struktur solnych rozpoznanych w centralnej części basenu polskiego, zwanej bruzdą środkowopolską (Fig. 1). Struktura Mogilna ma około $30 \mathrm{~km}$ długości i ponad 7 km szerokości o elongacji NW-SE (Fig. 1, 2). Zwierciadło solne znajduje się na głębokości około $250 \mathrm{~m}$, a spąg autochtonicznego cechsztynu zalega na głębokości około $6 \mathrm{~km}$. Na potrzeby działalności górniczej wysad jest podzielony na dwie części: południowo-wschodnią, określoną jako złoże Mogilno I, w której prowadzona jest eksploatacja soli metodą otworową przez IKS Solino SA, oraz północno-zachodnią, określoną jako złoże Mogilno II, w której otworową eksploatację soli prowadzi Investgas SA w celu tworzenia podziemnych magazynów gazu KPMG Mogilno. Obecnie w 11 kawernach magazynowane jest $589.3 \mathrm{mln} \mathrm{Nm}^{3}$ gazu. Docelowo planowana jest działalność 20-25 kawern o łącznej pojemności około $1.8 \mathrm{mld} \mathrm{Nm}^{3}$ (pojemność operacyjna $1.2 \mathrm{mld} \mathrm{Nm}^{3}$ ). W celu wyboru optymalnej lokalizacji komór magazynowych niezbędne są kompleksowe badania geologiczne budowy wewnętrznej wysadu. Szczegółowe badania mineralogiczno-petrograficzne skał ewaporatowych otworów Z-9 i Z-17, przeprowadzone w Akademii Górniczo-Hutniczej w Krakowie na zlecenie Investgas SA, są jednym z elementów tych prac. 
W rdzeniach ww. otworów stwierdzono cztery główne rodzaje skał:

- sole kamienne,

- sole potasowo-magnezowe,

- zubry i sole ilaste,

- anhydryty.

Sole kamienne występują w następujących odmianach petrograficznych:

- Sole kamienne biale i bialoszare - należą do osadów cyklotemu PZ-2 i są dominującymi skałami w badanych otworach (Fig. 3, 4). Występują wraz z nielicznymi przewarstwieniami innych ewaporatów w całym interwale wierceń, tj. od zwierciadła solnego (ok. 250 m p.p.t.) do głębokości 1695 m (otw. Z-17). Są to sole bardzo czyste, zawierające przeważnie powyżej $97.5 \% \mathrm{NaCl}$ (Tab. 1, 2). W częściach nierozpuszczalnych dominują euhedralne i subhedralne kryształy anhydrytu, tworzące liniowe koncentracje między blastami halitu (Fig. 5B) lub grupujące się wokół blastów (Fig. 5A). Ze względu na duże miąższości, dobrą lityfikację skały oraz brak znaczących domieszek innych minerałów sole te są najlepszym górotworem do lokalizacji kawen magazynowych.

- Sole szaropomarańczowe - o różnym stopniu zanieczyszczenia anhydrytem i minerałami ilastymi, występują tylko w otworze Z-9 i należą do ewaporatów cyklotemu PZ-3. Razem z warstwami zubru, anhydrytu i soli K-Mg tworzą silnie zredukowane, kilkumetrowe sekwencje tego ogniwa wśród soli starszych (Fig. 3). Zawartość części nierozpuszczalnych w tych solach waha się od $2.5 \%$ do $3.8 \%$ (Tab. 1).

- Sole pomarańczowe czyste i sole dymne - stwierdzone tylko w otworze Z-17 (Fig. 4), wraz z zalegającym poniżej blokiem anhydrytu głównego stanowią spągowe partie cyklotemu PZ-3. Są to sole bardzo czyste, o zawartości NaCl powyżej 98\% (Tab. 2). Pomimo wyraźnej różnicy w zabarwieniu są warstwami stratygraficznie sąsiednimi, genetycznie ze sobą związanymi. Sole dymne zostały po raz pierwszy udokumentowane w polskim cechsztynie i mają swój odpowiednik w cechsztynie niemieckim. Sole pomarańczowe i dymne zawierają nieznaczne domieszki anhydrytu sylwinu, kizerytu i boracytu. W przestrzeniach międzyziarnowych nielicznie pojawiają się inkluzje węglowodorów (Fig. 5E).

Sole potasowo-magnezowe reprezentowane są w obu profilach przez nieliczne laminy i cienkie warstewki soli twardej sylwinitowo-kizerytowej, o maksymalnej miąższości do kilkudziesięciu centymetrów. Skała jest zbudowana z trzech głównych minerałów, występujących w zmiennych proporcjach: halit (30-70\%), sylwin (10-35\%) i kizeryt (10-30\%) (Tab. 3, 4, Fig. 6A). Ziarna kizerytu o większej sile blastezy tworzą izometryczne, zbliźniaczone blasty w masie halitowo-sylwinowej (Fig. 5C, D). W niewielkich ilościach występują: anhydryt, kainit i polihalit. W nierozpuszczalnym w wodzie residuum stwierdzono chloryt, talk, kalcyt i magnezyt (Fig. 6B). Ponadto w masie solnej tkwią kilkumilimetrowe klasty węglanowe, inkrustowane kwarcem detrytycznym i pirytem. Na obrzeżach klastów występuje wtórny gips włóknisty (Fig. 5F).

Wiele cech mineralogiczno-petrograficznych wskazuje na to, że sól twarda jest utworem epigenetycznym, powstałym w wyniku rekrystalizacji z krążących w szczelinach skalnych nasyconych roztworów solnych. 
Zubry i sole ilaste tworzą dwa kilkudziesięciocentymetrowe przeławicenia wśród skał chlorkowych cyklotemu PZ-3. Występują w otworze Z-9, na głębokościach $863 \mathrm{~m}$ i 1113 m (Fig. 3). Składniki ewaporatowo-terygeniczne nie są wymieszane równomiernie. Halit ma barwę białoszarą, różowoszarą do brunatno-czerwonej, substancja ilasta jest popielatoszara i brunatno-szara; występuje w formie rozproszonej pomiędzy blastami halitu oraz tworzy kilkunastomilimetrowe koncentracje ilasto-solne (Fig. 7A, B). Proporcja halitu do nierozpuszczalnego w wodzie residuum wynosi około $86 \%$ do 14\%. Głównymi składnikami skał zubrowych są: halit, anhydryt, chloryt, illit, kwarc oraz magnezyt (Tab. 3, Fig. 8).

Anhydryty występujące w rejonie otworów Z-9 i Z-17 nie tworzą ciągłych, zwartych pokładów ani warstw, ich kontakt ze skałami otaczającymi jest przeważnie tektoniczny. W otworze Z-9 stwierdzono trzy kilkunastocentymetrowe rozczłonkowane warstwy, występujące wśród ewaporatów cyklotemu PZ-3 (zubrów, soli pomarańczowych zailonych i soli potasowo-magnezowych). Wiele cech wskazuje, że jest to jedna warstwa dwu- lub trzykrotnie powtórzona w profilu. Otwór Z-17 przewierca natomiast kilkunastometrowy blok anhydrytu głównego, niezgodnie zalegający pomiędzy solami młodszymi dymnymi i starszymi białoszarymi. Blasty anhydrytu wykształcone są euhedralnie, subhedralnie i anhedralnie (Fig. 7C-F), tworząc często tekstury płaskorównoległe. Skały anhydrytowe zawierają laminy węglanowe, zbudowane głównie z magnezytu (Fig. 7E, 9) oraz epigenetyczne gniazda polihalitowo-halitowe o zabarwieniu mlecznozielonym (Fig. 10). Badania mikroskopowe wykazały, że szczelinowatość skał ewaporatowych w miejscu wykonania otworów Z-9 i Z-17 jest znikoma (Tab. 5, 6). W solach kamiennych obserwuje się szczeliny o wielkości poniżej jednego mikrona. Szczeliny o wielkości powyżej jednego mikrometra stwierdzono głównie w partiach profilu w którym znajduje się duża ilość lamin anhydrytowych bądź w samych anhydrytach. W większości przypadków szczelinki są zamknięte. Powoduje to, że wędrówka węglowodorów w solach kamiennych jest w tym rejonie wysadu znikoma lub praktycznie nie istnieje.

Podsumowanie:

- Otwory Z-9 i Z-17 nawiercają skały ewaporatowe i silikoklastyczne cechsztyńskiej serii solnej cyklotemów PZ-2 i PZ-3. Utwory te są uformowane tektonicznie. Warstwy zalegają pod kątem od $60^{\circ}$ do $90^{\circ}$. Tylko w niektórych fragmentach profilu, głównie w grubych kompleksach soli kamiennych, obserwuje się naturalne (sedymentacyjne) następstwo warstw.

- Obserwowane w profilach (Fig. 3, 4) następstwo warstw jest astratygraficzne. W stropowych i spągowych partiach badanych otworów występują starsze sole kamienne (Na-2), natomiast w części środkowej odsłaniają się cienkie, zredukowane serie soli młodszych (Na-3), rozdzielonych tektonicznie warstwami soli starszych. Wiele ogniw jest zredukowanych lub wyklinowanych całkowicie. Skały sztywne, takie jak anhydrytowce, łupki czy zubry, są sfragmentaryzowane.

- Ewaporaty cyklotemu PZ-2 reprezentowane są przez sole kamienne białe i białoszare oraz nieliczne, cienkie wkładki soli potasowych, wykształconych jako sól twarda sylwinowo-kizerytowa.

- Skały cyklotemu PZ-3 budują sole kamienne pomarańczoworóżowe czyste i zailone, sole kamienne dymne, zubry oraz laminy i cienkie warstewki anhydrytów i soli potasowo-magnezowych (sól twarda j.w. oraz sole potasowe bezkizerytowe). 
- W rozkładzie granulometrycznym residuum (Tab. 1, 2, Fig. 11) zaobserwowano prawidłowość powtarzającą się konsekwentnie we wszystkich analizowanych próbkach soli kamiennej. W solach kamiennych cyklotemu PZ-2 zdecydowana większość części nierozpuszczalnych mieści się w przedziale $0.25-2.0 \mathrm{~mm}$, natomiast w solach kamiennych cyklotemu PZ-3 części nierozpuszczalne mają mniejsze rozmiary i należą do frakcji $<0.25 \mathrm{~mm}$. Zróżnicowanie to jest związane głównie z wielkością ziaren anhydrytu. Powyższa wyraźna różnica w rozkładzie granulometrycznym jest jedną z ważnych petrograficznych cech diagnostycznych pozwalających odróżniać sole kamienne starsze (Na-2) od soli kamiennych młodszych (Na-3).

- W badanych skałach ewaporatowych i silikoklastycznych otworów Z-9 i Z-17 stwierdzono występowanie 18 minerałów, takich jak: halit, sylwin, kizeryt, epsomit, polihalit, kainit, anhydryt, gips, boracyt, magnezyt, dolomit, kalcyt, kwarc, talk, chloryt, illit, piryt, hematyt. Szczegółowa charakterystyka tych minerałów będzie przedmiotem oddzielnego opracowania. 